\title{
Pharmacological treatment approaches to ADHD in Norway and Serbia
}

\author{
Vukica Bogosavljevic
}

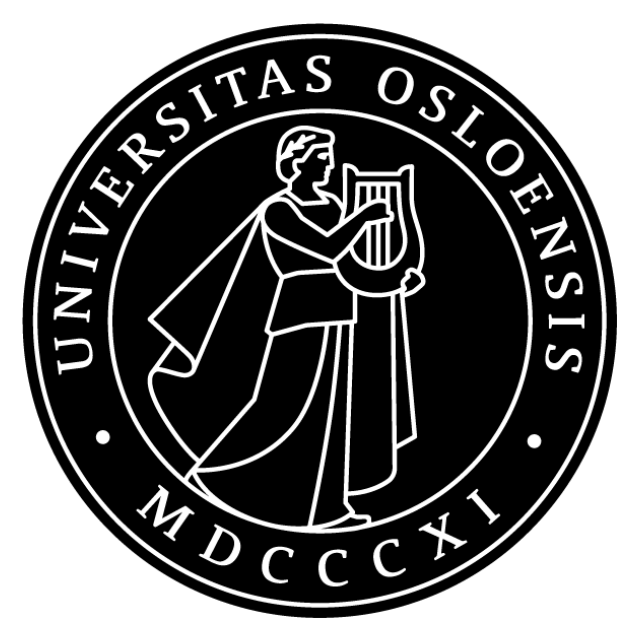

Master thesis in Social Pharmacy

School of Pharmacy

UNIVERSITY OF OSLO

Fall 2016 


\section{Pharmacological treatment approaches to ADHD in Norway and Serbia}

Vukica Bogosavljevic

Master thesis in Social Pharmacy

School of Pharmacy,

Faculty of Mathematics and Natural Sciences,

University of Oslo

2016 
(C) Vukica Bogosavljevic

2016

Pharmacological treatment approaches to ADHD in Norway and Serbia Vukica Bogosavljevic

http://www.duo.uio.no/

Print: Reprosentralen, Universitetet i Oslo 


\section{Abstract}

Introduction - Attention deficit hyperactivity disorder (ADHD) is a psychiatric disorder characterized by inattention, hyperactivity and/or impulsivity. It is predominantly a disorder of childhood, but it can also be diagnosed in adults. Prevalence of ADHD varies worldwide and more boys will get diagnosed and treated than girls. In many countries the prevalence is not well investigated and there are no national guidelines for ADHD treatment. Currently there is no single test available to diagnose ADHD. The aim of this study is to describe and compare the use/sale of ADHD medicines in Norway and Serbia and to describe the possible differences in therapeutic approaches to ADHD in these two countries. Quality assessment of Serbian data was also conducted.

Materials and methods - This epidemiological study used open retail/wholesale data and additional data collected from the Clinic for Neurology and Psychiatry for Children and Youth (CNPCY), in Belgrade, Serbia. Norwegian retail data and the study population was acquired from the Norwegian National Prescription Registry (NorPD) while the Norwegian wholesale data used in this study can be found in the annual report "Drug Consumption in Norway" published by the Norwegian Institute of Public Health (NIPH). Serbian wholesale data was acquired from the Agency for Medicines and Medical Devices of Serbia (ALIMS), while the population data used in this study was acquired from the CNPCY in Belgrade, Serbia.

Results - Use of methylphenidate was on average 200 times larger in Norway than in Serbia during the observed period 2007-2013 when expressed in DDD/1000 inhabitants/day. Trends regarding the increase in use per year were similar in both countries, and the observed growth per year was approximately 10\% when expressed in DDD/1000 inhabitants/day. In Serbia $90 \%$ of all ADHD cases were males, while in Norway $60 \%$ were males. $50 \%$ of all ADHD medication users were in the age group 10-14 years in both countries. Serbian data is found not to be of bad quality, it is just less accessible and of less coverage than Norwegian data. Serbian wholesale data regarding ADHD medications is assessed to be complete and of good quality because of the fact that narcotic drugs are thoroughly monitored in Serbia. 
Conclusion - Pharmacological treatment approaches to ADHD in Norway and Serbia are different. While in Norway both atomoxetine and dexamphetamine are used in addition to methylphenidate, in Serbia only methylphenidate is registered for ADHD treatment. Further research is needed to identify ADHD prevalence in Serbia and to determine whether or not ADHD is over-diagnosed in Norway and/or under-diagnosed in Serbia. It is also important to establish how big of a role do different genetic, cultural and diagnostic factors play in ADHD. 


\section{Sammendrag}

Innledning - ADHD er en psykiatrisk lidelse preget av oppmerksomhetssvikt, hyperaktivitet og /eller impulsivitet. Det er hovedsakelig en forstyrrelse i barndommen, men kan også bli diagnostisert hos voksne. Forekomst av ADHD viser en stor variasjon over hele verden og flere gutter vil bli diagnostisert og behandlet enn jenter. I mange land er forekomsten ikke godt nok unders $\varnothing \mathrm{kt}$ og det finnes ingen nasjonale retningslinjer for ADHD behandling. Foreløpig er det ingen spesifikke tester for å diagnostisere ADHD. Målet med denne studien er å beskrive og sammenligne bruk/salg av ADHD legemidler i Norge og Serbia og beskrive eventuelle forskjeller i terapeutiske tilnærminger til ADHD behandling i disse to landene. Kvalitetsvurdering av serbiske data ble også gjennomført.

Materialer og metoder - Denne epidemiologiske studien bruker åpne detaljhandel/ engrosdata og ytterligere data som er samlet inn fra Klinikk for nevrologi og psykiatri for barn og ungdom (CNPCY) i Beograd, Serbia. Opplysninger angående detaljhandel og studiepopulasjon i Norge er hentet fra Reseptregisteret (NorPD), mens opplysninger angående engros som er brukt i denne studien finnes i den årlige rapporten "Legemiddelforbruket $\mathrm{i}$ Norge" utgitt av Folkehelseinstituttet. Opplysninger angående engrosdata i Serbia er hentet fra den serbiske legemiddelverket (ALIMS), mens opplysninger angående studiepopulasjon fra Serbia er hentet fra CNPCY i Beograd, Serbia.

Resultater - Bruk av metylfenidat uttrykt som DDD /1000 innbyggere/døgn var i gjennomsnitt 200 ganger større i Norge enn i Serbia under den observerte perioden 2007 2013. Tendensen til $\varnothing$ kning i bruk per år var lik i begge land, og den observerte veksten per år uttrykt som DDD/1000 innbyggere/døgn var ca. 10\%. 90\% av de som får diagnosen i Serbia er gutter, mens det i Norge er 60\%. 50\% av alle ADHD medisinbrukere var i aldersgruppen 10-14 år i begge land. Data fra Serbia viser seg å ikke være av dårlig kvalitet, men er mindre tilgjengelig og mindre omfattende enn data fra Norge. Engrosdata fra Serbia angående ADHD medisiner er vurdert å være komplett og av god kvalitet fordi narkotika er grundig overvåket i Serbia.

Konklusjon - Farmakologiske tilnærminger til ADHD behandling i Norge og Serbia er forskjellige. I Norge brukes både atomoksetin og dexamfetamin i tillegg til metylfenidat, 
mens det bare er metylfenidat som er registrert i Serbia. Videre forskning er nødvendig for å identifisere forekomst av ADHD i Serbia, og for å avgjøre hvorvidt ADHD er overdiagnostisert i Norge og/eller underdiagnostisert i Serbia. Det er også viktig å etablere hvor stor rolle ulike genetiske, kulturelle og diagnostiske faktorer utgjør for ADHD. 


\section{Preface}

This master thesis was conducted at the department of Social Pharmacy at the Faculty of Mathematics and Natural Sciences, School of Pharmacy, University of Oslo in the period of February to November 2016.

First and foremost, I would like to express my gratitude to my supervisor Ingunn Björnsdóttir, associate professor at the School of pharmacy, University of Oslo, for her help and guidance during my research.

Secondly, I would like to thank my external contact and supervisor from Serbia Dejan Stevanovic, MD PhD for all his help with acquiring data from Serbia and for his help in reviewing this thesis.

I would also like to thank Jela Milic professor at the Faculty of Pharmacy, University of Belgrade in Serbia, for her help and ideas about finding and acquiring Serbian data.

Furthermore, I would like to thank my sister Visnja Padjen, MD PhD for her help in reviewing this thesis and language advice.

Last but not least, I would like to thank my husband Nemanja Jeremic, Mpharm for his help and support.

Sandefjord, November 2016

Vukica Bogosavljevic 


\section{Table of contents}

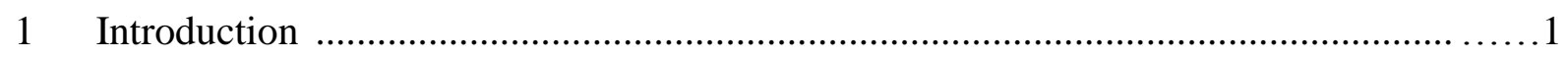

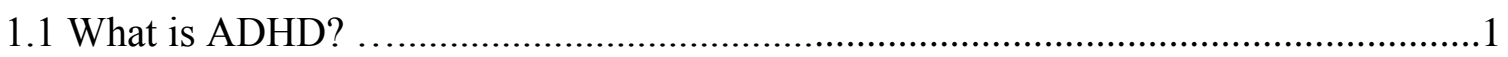

1.2 Worldwide prevalence of ADHD and male to female ratio........................2

1.3 Diagnosing ADHD .........................................................

1.4 Long-term outcomes and ADHD comorbidities..................................

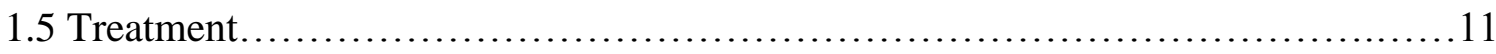

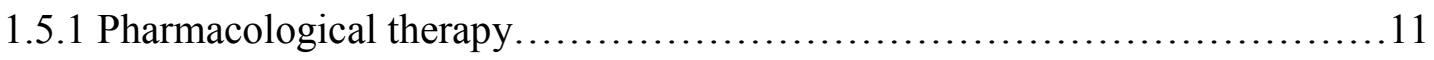

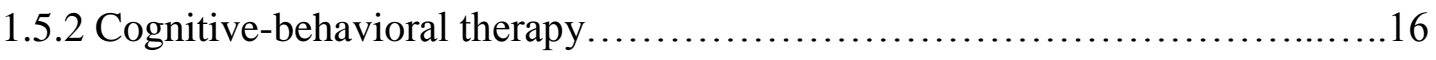

1.6 Adverse effects of stimulants............................................... 17

1.7 Health care systems in Norway and Serbia......................................19

1.8 Narcotic control regulations in Norway and Serbia.............................20

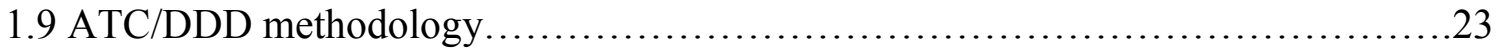

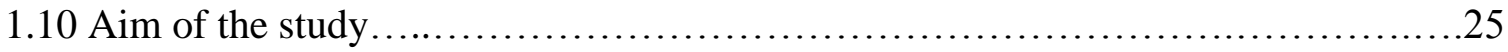

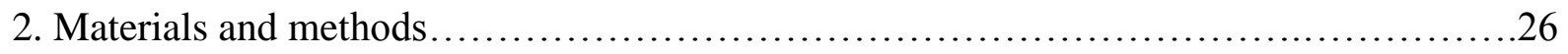

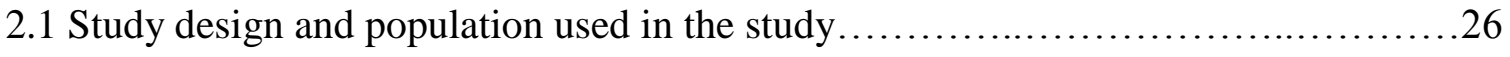

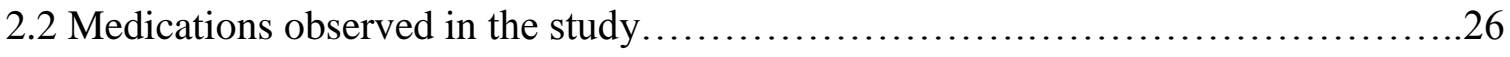

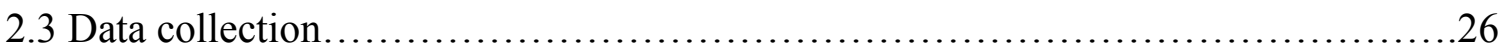

2.3.1 Data from Norway................................................26

2.3.2 Data from Serbia.................................................28

2.4 Quality assessment of drug sales data in Serbia...............................29

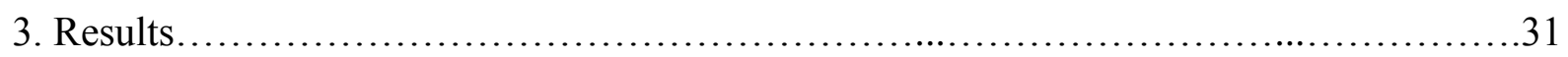

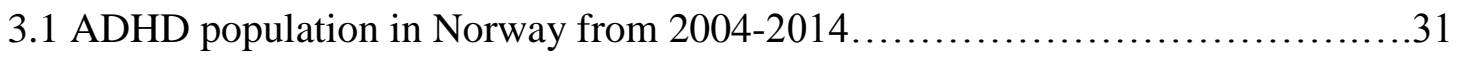

3.2 ADHD cases at the CNPCY in Belgrade, Serbia from 2010-2015...............32 
3.3 Number of users of methylphenidate, dexamphetamine and atomoxetine during the period of 2004-2014.

3.4 Use of ADHD medicines in Norway during the period of 2004-2014 expressed in DDD/1000/day of methylphenidate, dexamphetamine and atomoxetine. .35

3.5 ADHD population in Norway and Serbia distributed by age and gender from 20102014.

3.6 ADHD population distributed by gender in Norway and Serbia from 2010 2014.

3.7 Assigned treatment for ADHD patients in Serbia in 2015

3.8 Distribution of different methylphenidate formulations in Norway during the period of 2010-2014.

3.9 Comparison of methylphenidate use in Norway and Serbia expressed in DDD/ 1000 /day from 2007-2013.

3.10 Quality assessment of Serbian data.... .45

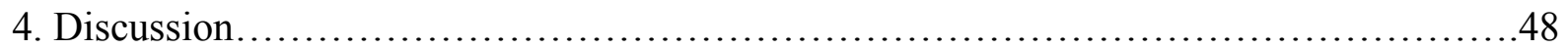

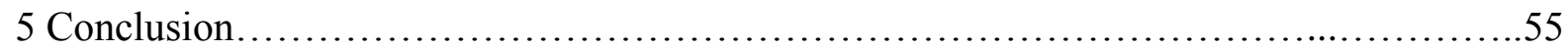

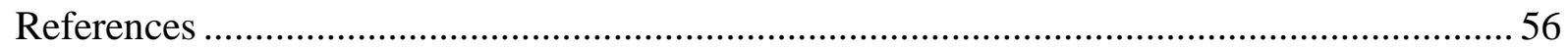

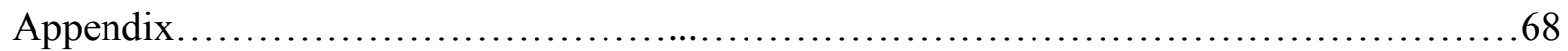




\section{Abbreviations}

ADHD - Attention deficit hyperactivity disorder

ALIMS - Agency for Medicines and Medical Devices of Serbia (in Serbian: Agencija za lekove i medicinska sredstva)

ATC - The Anatomical Therapeutic Chemical Classification System

CNPCY - Clinic for Neurology and Psychiatry for Children and Youth in Belgrade, Serbia DDD - Defined Daily Doses

DSM -5 - American Psychiatric Association's Diagnostic and Statistical Manual of Mental Disorders

HKD - Hyperkinetic disorder

ICD -10 - The International Classification of Mental and Behavioral Disorders $10^{\text {th }}$ revision.

NIPH - The Norwegian Institute of Public Health

NorPD - Norwegian National Prescription Registry (in Norwegian: Reseptregisteret)

OROS - Osmotic Controlled Release Oral Delivery System

PDD - The prescribed daily dose

RZZO - National Health Insurance Institution, in Serbian: Republicki Zavod za Zdravstveno Osiguranje

SLV - Norwegian Medicines Agency (in Norwegian: Statens legemiddelverk)

WHO - World Health Organization 


\section{List of tables}

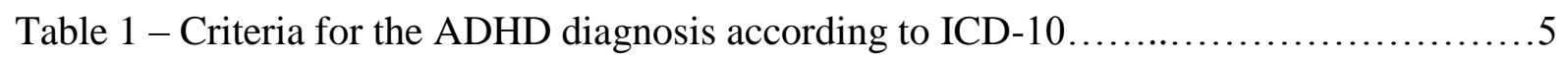

Table 2 - Presentations of ADHD according to DSM-5 ............................... 6

Table 3 - Typical symptoms of inattention....................................... 7

Table 4 - Typical symptoms of hyperactivity....................................

Table 5 - Typical symptoms of impulsivity......................................... 8

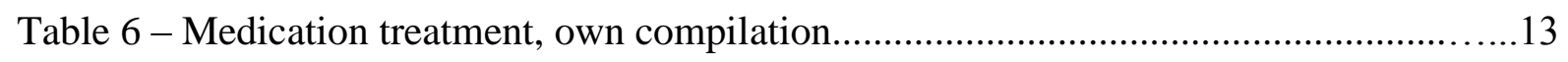

Table 7 - Drugs used for ADHD treatment in Norway, own compilation...................15

Table 8 - Drugs used for ADHD treatment in Serbia own compilation..................... 16

Table 9 - Common adverse effects of stimulants, own compilation........................18

Table 10 - Medications in Norway that are placed into the prescription group A and prescription group B according to the assessment of the Norwegian Medicines Agency.....21

Table 11 - Data sources for Norway and Serbia.....................................29 


\section{List of figures}

Figure 1 - Number of ADHD medication users per 1000 inhabitants per year in Norway from

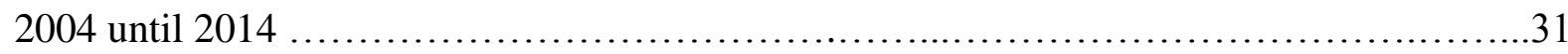

Figure 2 - Number of ADHD patients per year during the period of 2010-2015 at the CNPCY in Belgrade, Serbia. .32

Figure 3 - The ratio of ADHD patients out of all patients at the CNPCY in Belgrade, Serbia during the period of $2010-2015$

Figure 4 - Number of new ADHD cases expressed as the ratio of total number of patients at CNPCY, Belgrade, Serbia during the period of 2010-2015

Figure 5 - Number of users of methylphenidate, dexamphetamine and atomoxetine in Norway during the period of $2004-2014$. .34

Figure 6 - Use of methylphenidate in Norway expressed in DDD/1000/day during the period of 2004-2014.

Figure 7 - Use of dexamphetamine in Norway expressed in DDD/1000/day during the period of 2004-2014

Figure 8 - Use of atomoxetine in Norway expressed in DDD/1000/day during the period of 2004-2014. .36

Figure 9 - ADHD medication users distributed by age in Norway and Serbia expressed in percentage and divided in age groups: 4 years or younger, 5-9 years, 10-14 years, 15-19 years.

Figure 10 - Number of male ADHD medication users in Norway and Serbia expressed in percentage and divided in age groups:4 years or younger,5-9 years,10-14 years, 15-19 years. 
Figure 11 - Number of female ADHD medication users in Norway and Serbia expressed in percentage and divided in age groups: 4 years or younger, 5-9 years, 10-14 years, 15-19 years.

Figure 12 - ADHD population from Norway and Serbia distributed by gender and expressed in percentage from 2010-2014..... 40

Figure 13 - The pie chart that shows the percentage of patients in 2015 who received one of three therapy alternatives: Concerta, Risperidone or cognitive-behavioral (CBT) therapy, parental counseling and other non-pharmacological treatment in Serbia....

Figure 14 - Distribution of different methylphenidate preparations (ATC code N06BA04) in

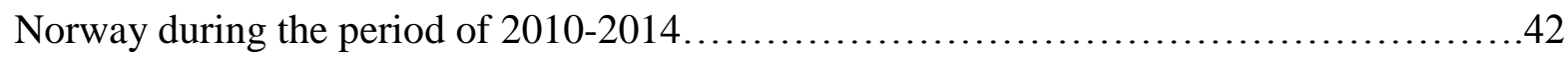

Figure 15 - Direct comparison of methylphenidate use in Norway and Serbia expressed in DDD/1000/day during the period of 2007-2013 



\section{Introduction}

\subsection{What is ADHD?}

Attention deficit hyperactivity disorder (ADHD) is a very common psychiatric disorder that affects first and foremost children and adolescents. It is a psychiatric disorder characterized by inattention, hyperactivity and/or impulsivity that interferes with functioning or development (1). Even though it is predominantly a disorder of childhood, it can also be diagnosed in adults. Recent studies have shown that 30-50\% of children with ADHD continue to live with its burden in adulthood as well (2).

The International Classification of Mental and Behavioral Disorders $10^{\text {th }}$ revision (ICD-10) defines ADHD as a hyperkinetic disorder (HKD) (3). This term is widely used in Europe and in European guidelines (3). HKD is a persistent and severe impairment of psychological development, characterized by early onset of overactive, poorly modulated behavior with marked inattention and lack of persistent task involvement. In North America the condition is identified as ADHD using the American Psychiatric Association's Diagnostic and Statistical Manual of Mental Disorders (DSM-5) criteria which has a broader, more inclusive definition that consequently comprehends a number of different ADHD subtypes (4).

The cause of ADHD is unknown. It is believed that both genetics and environmental factors are responsible for the condition (5). Even though it is widely accepted that primarily the dopamine neurotransmission is disrupted in ADHD, norepinephrine is also involved and their deficit may be the underlying causes of ADHD symptoms such as inattention and impulsivity (6). 


\subsection{Worldwide prevalence of ADHD and male to female ratio}

Prevalence of ADHD varies worldwide, ranging from 3\% to $9 \%$ among children (7) and 2-4\% in adults (8). Moreover, prevalence varies across countries significantly. In Europe it is considered that the disorder is underdiagnosed and undertreated, especially in adults (9). On the other hand, some argue that ADHD is over-diagnosed and over-treated especially in the United States of America (10). In order to determine the prevalence across countries several studies have been conducted $(7,8)$ with the objective to determine whether the variation in prevalence was greater than expected by chance. Data regarding prevalence was gathered from ADHD studies conducted on different continents. The data was used to determine an overall prevalence estimate based on all studies. Since these studies found that the difference in prevalence is greater than expected by chance, the next step was to determine which variables affect the results. The most important identified variables were method of ascertainment of the sample (community or school), sample size, diagnostic criteria (DSM-5 or ICD-10) and source of information (parents, teachers or self-reports). The conclusion was that the prevalence of ADHD is higher when using the DSM-5 diagnostic criteria and when the teachers are included in reporting ADHD cases $(7,8)$. This offers a potential explanation why the prevalence could be lower in some countries where the ICD-10 is used and teachers are not readily included in recognizing ADHD in children.

In many European countries, like Serbia for instance, the prevalence is not well investigated and there are no national guidelines for ADHD treatment. In Norway 5 persons (children and adults) per 1,000 inhabitants were treated with an ADHD drug in 2007 (11).

In population-based studies male to female ratio is reported to be 3:1 (12), while in clinical trials it is 5:1 (13). These numbers show that in children, more boys will get diagnosed and treated compared to girls. Why is there such a substantial difference between community and clinical findings? One of the possible explanations can be the fact that girls with ADHD are less impulsive, less aggressive and less hyperactive compared to boys with ADHD (14). However, since the change of the diagnostic criteria has been introduced more and more girls are being diagnosed with the disorder. This change in the diagnostic criteria can also be the 
reason for the increase of stimulant medication use in ADHD treatment in the past decade. This increase is measured in Defined Daily Dose (DDD). DDD is a unit of measurement used to study changes in drug consumption over time (15). Furthermore, since nowadays ADHD is considered as an illness that can also be registered in adulthood, more and more adults are getting treated (16). However, there are significant variations worldwide. In some countries there are a lot of adults that get treated for ADHD with stimulants (16), while in other counties, like Serbia for example, people are not allowed to use stimulants after the age of 18 because ADHD is still regarded as an illness that is seen only in childhood. Consequently, if a person still suffers from ADHD symptoms in adulthood he or she is treated with cognitive behavioral therapy mainly or using antipsychotics (17). 


\subsection{Diagnosing ADHD}

Currently there is no single test available to diagnose ADHD/HKD. Diagnosis is made by using data collected during the clinical assessment based on the classification system: DSM-5 or ICD-10 $(3,4,9)$. In both Norway and Serbia only physicians who are specialized in psychiatry can initiate the treatment. In Norway ADHD medication can be prescribed by general practitioners if the treatment had been initiated by a specialist. As previously mentioned there are two systems: The International Classification of Mental and Behavioral Disorders $10^{\text {th }}$ revision (ICD-10) (3), and the American Psychiatric Association's Diagnostic and Statistical Manual of Mental Disorders - 5th Edition (DSM-5) (4). The ICD-10 system is used to diagnose ADHD in both Norway and Serbia. However, in Norway the DSM-5 is used on some occasions. When prescribing stimulants, a hospital doctor in Norway can choose to use the DSM-5 instead for ICD-10 (18). According to the ICD-10 ADHD is defined as "Behavioral and emotional disorder with onset usually occurring in childhood and adolescence" and its diagnosis code is F90. The diagnosis code F90 can be used regardless of the patient's age because the diagnosis generally has onset within the childhood years and can continue throughout adult life.

As stated earlier the ICD-10 uses the term "Hyperkinetic disorder", while the DSM-5 uses the term "Attention deficit disorder with hyperactivity". There is a slight difference between the two terms. To be diagnosed with HKD according to ICD-10, a person must have all of the following: inattention, hyperactivity and impulsivity. This is not the case for DSM-5 where a person can be diagnosed with ADHD while only having inattention (with or without hyperactivity). As regards to patient's age and ADHD, the DSM-5 does not demand the same number of symptoms for both children and adults which makes the diagnosis more including compared to HKD/ICD-10.

According to ICD-10, HKD is defined as a persistent and severe impairment of psychological development and is characterized by early onset of symptoms (before 6 years of age) and by long duration (3) (Table 1). 
Table 1: Criteria for the ADHD diagnosis according to ICD-10 (3)

\section{Criteria for the ADHD diagnosis according to ICD-10}

1) Poorly modulated behavior with marked inattention and lack of persistent task involvement

2) Symptoms are seen prior to the age of six and are of long duration

3) Impairment must be present in two or more settings

4) Anxiety disorders, mood affective disorders, pervasive developmental disorders and schizophrenia must be excluded

According to DSM-5 there are three presentations of ADHD (Table 2):

- Combined presentation (F90.2), if both inattention and hyperactivity-impulsivity were present for the past 6 months.

- Predominantly inattentive presentation (F90.0), if the criteria of inattention is met but hyperactivity-impulsivity was not present for the past 6 months

- Predominantly hyperactive/impulsive presentation (F90.1), if the criteria of hyperactivity-impulsivity is met but inattention was not present for the past 6 months. 
Table 2: Presentations of ADHD according to DSM-5 (4).

\begin{tabular}{|c|c|c|}
\hline \multicolumn{3}{|c|}{ Presentations of ADHD according to DSM-5 } \\
\hline $\begin{array}{l}\text { Combined presentation } \\
\text { (F90.2) }\end{array}$ & $\begin{array}{l}\text { Predominantly inattentive } \\
\text { presentation }(\mathrm{F90.0})\end{array}$ & $\begin{array}{l}\text { Predominantly } \\
\text { hyperactive/impulsive } \\
\text { (F90.1) }\end{array}$ \\
\hline $\begin{array}{l}\text { - All three features are } \\
\text { present } \\
\text { - } 6 \text { or more symptoms of } \\
\text { hyperactivity/impulsivity are } \\
\text { present }\end{array}$ & $\begin{array}{l}\text { - } 6 \text { or more symptoms of } \\
\text { inattention are present } \\
\text { - less than } 6 \text { symptoms of } \\
\text { hyperactivity/impulsivity are } \\
\text { present }\end{array}$ & $\begin{array}{l}\text { - } 6 \text { or more symptoms of } \\
\text { hyperactivity/impulsivity are } \\
\text { present } \\
\text { - less than } 6 \text { symptoms of } \\
\text { inattention are present }\end{array}$ \\
\hline $\begin{array}{l}\text { - } 6 \text { or more symptoms of } \\
\text { inattention are presents } \\
\text { - Symptoms have persisted } \\
\text { for more than } 6 \text { months }\end{array}$ & $\begin{array}{l}\text { - Symptoms have persisted } \\
\text { for more than } 6 \text { months }\end{array}$ & $\begin{array}{l}\text { - Symptoms have persisted } \\
\text { for more than } 6 \text { months }\end{array}$ \\
\hline
\end{tabular}

With this taken into account the HKD (ICD-10 diagnosis) can be considered as a subgroup of the DSM-5 defined as combined presentation of ADHD (4). In other words, if considered as a continuum, HKD (the ICD-10 diagnosis) actually represents the most severe form of the DSM-5 ADHD $(4,19)$.

Regarding the ADHD symptoms, they are defined as a persistent pattern of inattention, hyperactivity and impulsivity that can present differently from patient to patient (Table 3,4,5). 
Table 3: Typical symptoms of inattention $(3,4)$

\section{Typical symptoms of inattention}

- Difficulty in sustaining attention and easily distracted by extraneous stimuli

- Difficulty in following instructions and completing tasks

- Forgetfulness in everyday activity

- Difficulty in organizing tasks

- Avoidance of activities that demand sustained mental effort

- Not listening when spoken to directly

- Careless mistakes and no attention to detail

Table 4: Typical symptoms of hyperactivity $(3,4)$

\section{Typical symptoms of hyperactivity}

- Getting up from a seat when he or she is supposed to remain seated

- Excessive talkativeness

- Restlessness

- Inability to engage in leisure activities quietly 
Table 5: Typical symptoms of impulsivity $(3,4)$

\section{Typical symptoms of impulsivity}

- Difficulty awaiting turn

- Impatience

- Interruption of others and their activities

These symptoms would interfere with everyday functioning and would lead to long-term impairment (4).

Regarding ADHD diagnosing and treatment there is a need to explore the impact of different policy approaches with respect to health-economic and patient-safety issues, with the ultimate goal being rational use of medicines. 


\subsection{Long-term outcomes and ADHD comorbidities}

Long-term follow up studies of children with ADHD have shown that one-third (20) to twothirds (21) of children with ADHD symptoms continue to demonstrate these symptoms as adults. The symptoms of inattentiveness and impulsivity persist longer in adulthood than hyperactivity (22). Adults with ADHD are more susceptible to unemployment as they are often fired due to tardiness, inter-office conflict because of the inability to meet deadlines or to accomplish expected workloads. It is very common that adults with ADHD go through a number of jobs until they find fit in considering the job requirements and their individual strengths (23). It is also common for parents with ADHD to have children with ADHD (24). This can lead to significant difficulties since parents have a very important role in the treatment of their children (24).

There are not too many studies on the long-term outcome of ADHD treatment, but almost all recent ones had come to similar conclusion. A systematic review published in 2015 has shown that there is a lack of evidence about the long term effects of methylphenidate in children and adolescents with ADHD (25). A recent European study however had shown that initial pharmacological treatment had benefits on symptom relief only in the short-term, while no beneficial impact on ADHD outcomes or overall functioning was found (26). Another study regarding treatment strategies for ADHD that was a 14-month randomized clinical trial that demonstrated the short-term efficacy of pharmacotherapy and behavioral therapy for ADHD (27). This study concluded that medication management was superior to behavioral treatment. One study has found that not even combined treatment had great benefits in management of ADHD symptoms in the long-term (28). However, there was another study regarding the evaluation of ADHD treatments that had different findings. This study has shown that the combination of pharmacological and non-pharmacological treatment is most associated with long-term improvements (29).

There are a number of comorbid conditions that commonly occur alongside ADHD. About $65 \%$ of all children with ADHD develop one or more comorbid condition (30). About $20 \%$ of children with ADHD have mood disorders and/or conduct disorders (30). About $60 \%$ of children with Tourette syndrome have ADHD (31). Autistic spectrum disorder is also 
recognized as a comorbidity of ADHD. Hyperactivity can actually mask the features of autistic spectrum disorder (32). Learning disabilities are also reported. It is estimated that $70 \%$ of children and adolescents with ADHD also have some type of learning disability (33). Furthermore, the risk of substance abuse is increased in children and adults with ADHD, and it is described that the risk for drug abuse is even greater if an ADHD patient has a comorbid conduct disorder or bipolar disorder (34). However, it is well documented that unmedicated subjects with ADHD have an even higher risk for substance misuse compared to subjects with ADHD that are on medication. In other words, pharmacotherapy was associated with an $85 \%$ reduction in risk for substance abuse in $\operatorname{ADHD}$ patients, especially in youth $(35,36)$. 


\subsection{Treatment}

So far there have been three kinds of treatment for ADHD with proven efficacy: psychotropic medication (stimulants and non-stimulants), cognitive-behavioral therapies and the combination of the two $(3,4,16)$. All three methods have shown good short-term effects, but the long-term effects of the treatments, first of all of stimulants, are unclear because some studies have found benefits, while other studies found no benefits (37).

\subsubsection{Pharmacological treatment}

Stimulants are the basic pharmacological treatment for ADHD and the effectiveness rates are reported to be $70-80 \%$ (38). Stimulants include methylphenidate and amphetamine products (dexamphetamine). Stimulants affect primarily the dopaminergic system (39). Many studies of stimulant use in children with ADHD have been conducted and the findings are that these medications improve attention span, self-control, behavior and social functioning (40). There are two different pharmaceutical formulations: short acting (4 to 6 hours) and long acting (8 to 12 hours). Pharmaceutical formulations like Concerta and Ritalin-SR (sustained-release tablets) offer once-a-day dosing lasting from 8 to 12 hours $(41,42)$.

Methylphenidate acts primarily as a norepinephrine-dopamine reuptake inhibitor (NDRI). It shares part of its basic structure with catecholamines. Methylphenidate is most active at modulating levels of dopamine and to a lesser extent norepinephrine (43). Initial treatment with methylphenidate should begin with low doses $(5 \mathrm{mg}$ three times daily for immediaterelease preparations/ the equivalent dose for modified-release preparations) and the dose should be titrated against symptoms and side effects over 4-6 weeks. The dose should be increased according to response up to a maximum of $100 \mathrm{mg} /$ day for adults (19). Most commonly observed adverse effects of methylphenidate include appetite loss, dry mouth, anxiety/nervousness, nausea, changes in blood pressure, tics and insomnia (58).

Dextroamphetamine (dexamphetamine) is the more active dextrorotatory, or 'right-handed', enantiomer of the amphetamine molecule. It is both a releasing agent and reuptake inhibitor of dopamine and norepinephrine, but the effect on norepinephrine is weaker than its effect on dopamine (44). Initial treatment with dexamphetamine should begin with low doses and then 
doses should be titrated against symptoms and side effects over 4-6 weeks. Treatment should be given in divided doses increasing to a maximum of $20 \mathrm{mg} /$ day for children, doses up to 40/mg/day for children aged 6-18 may occasionally be required and for adults up to 60 $\mathrm{mg}$ /day (19). Side effects of dexamphetamine vary widely by age and from person to person and they include hypertension, tachycardia, blurred vision, dry mouth, excessive grinding of the teeth, nosebleed and tics (58).

Lisdexamfetamine is a pro-drug (which means that it is inactive until it gets metabolized in the body and then it produces a drug), it is administered once-daily for the treatment of $\mathrm{ADHD}$ and it requires the enzymatic hydrolysis of lysine from dexamphetamine in order to have pharmacologic effects (45). It was introduced as an alternative to dextroamphetamine/amphetamine formulation because according to some studies it has less abuse potential, especially compared with the immediate-release dextroamphetamine/amphetamine formulation (45).

Other medications used to treat ADHD include a non-stimulant medication such as atomoxetine, brand name Strattera, which is a selective norepinephrine reuptake inhibitor (SNRI) with primary effect on the noradrenergic system. It has been shown that it improves inattention, impulsivity, and hyperactivity which are the three main symptoms of ADHD (46). However, it has a gradual onset and the maximal effect can be seen after three weeks. If using atomoxetine, for those weighing up to $70 \mathrm{~kg}$, the initial total daily dose should be approximately $0.5 \mathrm{mg} / \mathrm{kg}$ and it should be increased after 7 days to approximately 1.2 $\mathrm{mg} / \mathrm{kg} / \mathrm{day}$. For those weighing more than $70 \mathrm{~kg}$, the initial total daily dose should be $40 \mathrm{mg}$ and it should be increased after 7 days up to a maintenance dose of $80 \mathrm{mg} /$ day. The usual maintenance dose for adults is either 80 or $100 \mathrm{mg}$ (19). A single daily dose should be given, but it can be divided into two doses in order to minimize side effects. A trial of 6 weeks on a maintenance dose should be allowed to evaluate the full effectiveness of atomoxetine (19). Side effects of atomoxetine include nausea, dry mouth, appetite loss, insomnia, fatigue and headache (58).

Adrenergic agonists like clonidine are used in combination with other medications to treat children. They can reduce symptoms of aggression and insomnia that are associated with stimulants (47) (Table 6). 
Table 6: Medication treatment, own compilation based on (48-50)

\begin{tabular}{|c|c|c|}
\hline \multicolumn{3}{|c|}{ Medication treatment of ADHD } \\
\hline Drug & Brand names & Usual dosage \\
\hline \multicolumn{3}{|l|}{ First line medications } \\
\hline $\begin{array}{l}\text { Methylphenidate Immediate } \\
\text { release }\end{array}$ & $\begin{array}{l}\text { Ritalin } \\
\text { Methylin }\end{array}$ & $10-20 \mathrm{mg}$ 2-3 times per day \\
\hline $\begin{array}{l}\text { Methylphenidate Modified } \\
\text { release }\end{array}$ & $\begin{array}{l}\text { Ritalin LA } \\
\text { Ritalin SR } \\
\text { Concerta } \\
\text { Equasium } \\
\text { Medikinet } \\
\text { Metadate ER } \\
\text { Metadate CD } \\
\text { Quillivant XR }\end{array}$ & $\begin{array}{l}10 \text { to } 40 \mathrm{mg} \text { every morning } \\
18 \text { to } 54 \mathrm{mg} \text { every morning } \\
10 \text { to } 30 \mathrm{mg} \text { every morning } \\
5 \text { to } 60 \mathrm{mg} \text { every morning }\end{array}$ \\
\hline $\begin{array}{l}\text { Dextroamphetamine } \\
\text { (Dexamphetamine) }\end{array}$ & $\begin{array}{l}\text { Attentin } \\
\text { Adderall } \\
\text { Adderall XR }\end{array}$ & $\begin{array}{l}5 \text { to } 15 \mathrm{mg} \text { twice per day, or } \\
5 \text { to } 10 \mathrm{mg} \text { three times per } \\
\text { day }\end{array}$ \\
\hline Lisdexamfetamine & $\begin{array}{l}\text { Elvanse } \\
\text { Vyvanse }\end{array}$ & 30 to $70 \mathrm{mg}$ every morning \\
\hline
\end{tabular}




\begin{tabular}{|c|c|c|}
\hline \multicolumn{3}{|l|}{ Second line medications } \\
\hline Atomoxetine & Strattera & 18 to $60 \mathrm{mg}$ once per day \\
\hline \multicolumn{3}{|l|}{ Third line medications } \\
\hline Clonidine & $\begin{array}{l}\text { Catapresan } \\
\text { Catapres } \\
\text { Kapvay } \\
\text { Nexiclon } \\
\text { Clophelin }\end{array}$ & $\begin{array}{l}0.1 \text { to } 0.3 \mathrm{mg} \text { per day, } \\
\text { divided into three or four } \\
\text { doses }\end{array}$ \\
\hline $\begin{array}{l}\text { Bupropion (sustained and } \\
\text { extended release) }\end{array}$ & $\begin{array}{l}\text { Wellbutrin } \\
\text { Aplenzin, } \\
\text { Budeprion SR } \\
\text { Forfivo XL } \\
\text { Zyban }\end{array}$ & $\begin{array}{l}150 \mathrm{mg} \text { twice per day } \\
\text { (sustained release); } 150 \text { to } \\
300 \mathrm{mg} \text { once per day } \\
\text { (extended release) }\end{array}$ \\
\hline Imipramine & $\begin{array}{l}\text { Tofranil } \\
\text { Imipramine }\end{array}$ & 37.5 to $75 \mathrm{mg}$ twice per day \\
\hline Desipramine & Norpramin & $\begin{array}{l}50 \mathrm{mg} \text { twice per day, or } 100 \\
\mathrm{mg} \text { once per day }\end{array}$ \\
\hline Guanfacine & $\begin{array}{l}\text { Tenex } \\
\text { Intuniv }\end{array}$ & $\begin{array}{l}0.5 \text { to } 4 \mathrm{mg} \text { per day, divided } \\
\text { into two to four doses }\end{array}$ \\
\hline Risperidone & $\begin{array}{l}\text { Risperidone } \\
\text { Risperidal }\end{array}$ & \\
\hline
\end{tabular}


Treatment is usually initiated with low dose of the first line medications and then gradually titrated over two to four weeks until adequate response is achieved or adverse effects occur. Second line medications are considered if stimulants are not effective.

Some patients can have "drug holidays" during the weekends and/or summer holidays in order to limit adverse effects (58).

In Norway there are different kinds of medications from different manufactures used to treat ADHD. These include: Ritalin (both tablets and sustained-release capsules), Concerta (methylphenidate oros), Medikinet, Equasym (containing methylphenidate as active ingredient), Strattera (atomoxetine), Attentin (dexamphetamine) and Elvanse (lisdexamfetamine). In Serbia Concerta is the only registered drug used for ADHD, and all other drugs are not on the market. Off-label use in Serbia include clonidine and risperidone (Table 7,8).

Table 7: Drugs used for ADHD treatment in Norway, own compilation based on (49-51)

\begin{tabular}{|l|l|l|}
\hline \multicolumn{2}{|c|}{ Drugs used for ADHD treatment in Norway } \\
\hline Drug & Brand names & Registration status \\
\hline $\begin{array}{l}\text { Methylphenidate Immediate } \\
\text { release }\end{array}$ & Ritalin tablets & Registered \\
\hline $\begin{array}{l}\text { Methylphenidate Modified } \\
\text { release }\end{array}$ & Ritalin capsules & Registered \\
& Concerta & Registered \\
\hline Dexamphetamine & Equasium & Registered \\
\hline Lisdexamfetamine & Medikinet & Registered \\
\hline Atomoxetine & Eltentin & Registered \\
\hline
\end{tabular}




\begin{tabular}{|l|l|l|}
\hline Clonidine & Catapresan & $\begin{array}{l}\text { Registered but not for } \\
\text { ADHD (50) }\end{array}$ \\
\hline Risperidon & Risperidon & $\begin{array}{l}\text { Registered but not for } \\
\text { ADHD (51) }\end{array}$ \\
& Risperidal & \\
\hline
\end{tabular}

Table 8: Drugs used for ADHD treatment in Serbia own compilation based on (52)

\begin{tabular}{|c|c|c|}
\hline \multicolumn{3}{|c|}{ Drugs used for ADHD treatment in Serbia } \\
\hline Drug & Brand names & Registration status \\
\hline $\begin{array}{l}\text { Methylphenidate Modified } \\
\text { release }\end{array}$ & Concerta & Registered \\
\hline Clonidine & Catapresan & Not registered \\
\hline Risperidone & Risperidon & $\begin{array}{l}\text { Registered but not for } \\
\text { ADHD }\end{array}$ \\
\hline
\end{tabular}

\subsubsection{Cognitive-behavioral therapy}

The goal of cognitive-behavioral therapy is to teach self-control by using verbal selfinstructions, problem-solving strategies, cognitive modeling, self-monitoring, self-evaluation and self-reinforcement (53). This implies that a patient would have meetings with a therapist a couple of times a week where he/she would learn to control his/her inattention and impulsive behavior through modeling, role playing and practicing cognitive strategies. Available evidence from randomized controlled trials suggests that cognitive-behavioral therapy approaches are promising in producing significant symptom reduction (54). It is important to mention that cognitive-behavioral therapy is still present as the only form of treatment for adults with ADHD in some countries like Serbia where patients get stimulants prescribed only if they are younger than 18 years. 


\subsection{Adverse effects of ADHD medication}

Stimulants have adverse effects and some of them can be severe. The most common adverse effects are: headaches, stomachaches, insomnia, decreased appetite, weight loss, increase in blood pressure and irritability. Less frequent side effects are rebound effects, difficulty falling asleep, irritable mood and tics. It is unknown whether the tics are because of stimulants or the stimulants are "unmasking" an underlying disorder. These side effects are usually temporary and can be avoided by dosage change. If side effects interfere significantly another treatment can be considered (55) (Table 9).

Common side effects of atomoxetine are appetite suppression, sleep disturbance, jitteriness, and irritability, nausea and sedation. Atomoxetine can cause problems with sexual functioning (men can have difficulty with erections or experience impotence). Sedation can occur because of atomoxetine, but in that case the medication can be given in the evening instead of morning.

Substance abuse can also be considered as an adverse effect when using ADHD medicines (56). Euphoria is associated with intravenous injection or nasal inhalation of methylphenidate. Misuse or diversion of stimulants has been reported in adolescents in order to improve academic performance (studying, staying awake), to aid weight loss or in order to get "high" $(57,58)$. Use of the extended release tablets of stimulants is less prone to misuse because they are not easily crushed into powder for injection or snorting. Also extended release tablets have a once-per-day administration hence it is easier to follow how many tablets a person has used during a certain period of time (58). Atomoxetine does not appear to be associated with the risk of abuse and is therefore preferred in high risk cases (59).

As mentioned before, a person that is using stimulants could have a "drug holiday". A drug holiday can be very short (a few days, weekends) or very long (a few months or even years). Drug holiday is a good way to control the acute adverse effects of drugs (e.g. poor sleep) and it can also help reduce the chronic effects (e.g. increase in blood pressure). Another benefit of the drug holiday is counteracting the waning effectiveness of drugs after continuous use. This 
will interfere with the development of tolerance and it can reduce the need to increase the dose over time. Finally, the drug holiday can be taken in order to determine whether the drug is still effective after a period of long term use (58).

Drug holidays, can however be problematic for the child and family because the ADHD symptoms will often re-emerge or worsen during the period that medication is withheld. Despite their theoretical benefits, there is little evidence that drug holidays can help control side effects $(58,59)$.

Table 9: Common adverse effects of stimulants, own compilation based on (55-59)

Common adverse effects of stimulants

- Loss appetite

- Sleeplessness

- Tics

- Increase in blood pressure

- Headache 


\subsection{Health care systems in Norway and Serbia}

Health care system in both countries is delivered by means of a universal health care system. Universal health care system provides health care and financial protection to all citizens of a particular country, and its goal is to provide financial risk protection, improved access to health services, and improved health outcomes (60). Universal health care has important three dimensions: who is covered, what services are covered, and how much of the cost is covered (60). Universal health care is achieved by a mixed model of funding, usually with general taxation revenue as its primary source of funding with the option of private payment for services beyond those covered by the public system. In both Norway and Serbia health care system is publicly funded through taxation primarily. Some costs are borne by the patient, but the majority of costs are paid with the help of the compulsory insurance and tax revenues. Some programs are paid for entirely out of tax revenues. In some cases, the tax revenues are used either to fund insurance for the very poor or for those needing long term chronic care (61).

In Norway the universal health care is run and financed by the government. It covers physical and mental health for all (62). Health care system in Norway is heavily decentralized, and there are four designated Regional Health Authorities: Northern, Central, Western and SouthEastern Norway Regional Health Authority (63). Public hospitals in Norway are run by the four Regional Health Authorities.

Serbian constitution states that every citizen has the right to seek medical assistance free of charge (64). This is achieved by mutual contribution to the Compulsory Social Healthcare Fund of the National Health Insurance Institution (Republicki Zavod za Zdravstveno Osiguranje RZZO), but the amount of contribution depends on the person's income. 


\subsection{Narcotic control regulations in Norway and Serbia}

In Norway it is stated in the Narcotic Control Regulation (Narkotikaforskriften) that all substances, drugs and preparations are considered to be narcotics if they are listed on the Narcotic List which accompanies this law. There are now about 200 substances on this list, including amphetamines, cocaine, heroin, cannabis and other (65). It is important to state that this list can be updated and/or altered by administrative decision and thus it is not identical with the list in other countries.

According to the Drug Regulations (Legemiddelforskriften) a prescription drug is placed in the prescription group A, B or C. When deciding in which group the prescription drug should be placed, the following criteria are observed:

- Whether or not the drug in question is a substance that is classified as a narcotic or psychotropic according to international conventions

- Whether or not the drug in question if not used as recommended may be associated with serious risk of drug abuse, addiction or that it can be used for illegal purposes

- Whether or not the drug in question is a new substance that has certain characteristics and that may fall into this category as a precautionary measure.

A drug is placed into the prescription group A if one or more criteria stated above is met (66).

WHO defines addictive substances as substances that can create physical and/or psychological dependence. The user of these substances (referred to as addict) is periodically or chronically intoxicated and has great difficulty in voluntary ceasing substance use (67).

WHO also defines the term narcotic as a chemical agent that induces stupor, coma, or insensibility to pain (67). In other words, the term opioid is often used instead of the term narcotic even though these two expressions are not completely interchangeable. It is important to emphasize that the legal definition of a narcotic is more comprehensive than the 
"popular" perception of the term which would only include amphetamines, cocaine, heroin, cannabis. The narcotic list includes many drugs used therapeutically, i.e. so-called addictive drugs. Many of these medications, including six benzodiazepines and 15 opioids, are marketed in Norway (Table 10). These medications are placed into the prescription group A (drugs with high abuse potential) or B (medicines with abuse potential) according to the assessments by the Norwegian Medicines Agency $(64,65)$.

Table 10 - Medications in Norway that are placed into the prescription group A and prescription group B according to the assessments of the Norwegian Medicines Agency (49, $65,66)$.

\begin{tabular}{|l|l|}
\hline Prescription group A & Prescription group B \\
\hline Morphine & Clonazepam \\
\hline Oxycodone & Diazepam \\
\hline Hydromorphone & Oxazepam \\
\hline Fentanyl & Alprazolam \\
\hline Pethidine & Nitrazepam \\
\hline Ketobemidone & Tramadol \\
\hline Buprenorphine & Midazolam \\
\hline Methadone & Zopiclone \\
\hline Ketamine & Zolpidem \\
\hline Dexamphetamine & Codeine \\
\hline Methylphenidate & Ethylmorphine \\
\hline Flunitrazepam & \\
\hline
\end{tabular}


In Serbia it is stated by the Law on medicines and medical devices that the Agency for Medicines and Medical Devices of Serbia is obliged to collect and process data on sale and consumption of drugs and publishes them annually (68). This applies particularly for psychotropic substances as this is emphasized in both the Law of medicines and medical devices (68) and in the Law of psychotropic controlled substances (69). In these laws it is stated that the both wholesalers and retailers and obliged to keep records of all the psychotropic substances they work with. The Law of psychotropic controlled substances also defines what is considered a psychotropic controlled substance and it contains a list with these substances. Methylphenidate is on this list, as it is a psychotropic controlled substance (69, 70). Procedure regarding the dispensing of psychotropic controlled substances via prescription is explained by the Law of psychotropic controlled substances (69) and by the Ordinance on the prescription and dispensing of medicines (71). Prescription for psychotropic substances is always issued in two copies by a physician, where the other prescription is marked "copy" and is with a specified serial number from the book of records of issued prescriptions. The prescription copy is being kept at a pharmacy where the psychotropic medicine was dispensed together with input and output report of psychotropic substances. These reports and prescription "copies" of psychotropic medicines are subjected by a periodic police control. Both laws and the ordinance emphasize the obligation to follow the use/sale of psychotropic drugs by the pharmacies, physicians, ALIMS, distributers and even the police $(68,69,71)$. 


\subsection{ATC/DDD methodology}

ATC system classifies drugs into groups at 5 levels, gradually increasing in precision. The drugs are divided into 14 main groups ( $\left(1^{\text {st }}\right.$ level $)$, and then they are further divided into pharmacological/therapeutic subgroup ( $2^{\text {nd }}$ level). The $3^{\text {rd }}$ and $4^{\text {th }}$ levels are chemical/pharmacological/therapeutic subgroups and the $5^{\text {th }}$ level is the chemical substance (15).

For example, methylphenidate N06BA04:

- $\quad \mathbf{N}$ - Nervous system ( $1^{\text {st }}$ level, anatomical mail group)

- $\quad$ N06 - Psychoanaleptics ( $2^{\text {nd }}$ level, therapeutic subgroup)

- N06B - Psychostimulants, agents used for ADHD and nootropics $\left(3^{\text {rd }}\right.$ level, pharmacological subgroup)

- N06BA - Centrally acting sympathomimetics ( $4^{\text {th }}$ level, pharmacological subgroup)

- $\quad$ N06BA04 - Methylphenidate $\left(5^{\text {th }}\right.$ level, substance $)$

The ATC system makes it possible to compare the drug consumption on five different levels from the main group (for example the whole nervous system) down to consumption of each active ingredient (for example methylphenidate).

The ATC code for all pharmaceuticals on the Norwegian market can be found on the website of the national drug catalogue (Felleskatalogen) (49) and for the pharmaceuticals on the Serbian market can be found on the website of the Agency for Medicines and Medical Devices (ALIMS) (52).

The World Health Organization (WHO) classifies drugs and assigns them Defined Daily Doses (DDD) (15). 
As mentioned before, DDD is a statistical measure of drug sales, defined by WHO (15). It is used to standardize the comparison of drug usage between different drugs or between different health care environments. The DDD is not to be confused with the therapeutic dose or with the dose actually prescribed by a physician for an individual patient (PDD). The prescribed daily dose (PDD) is defined as the average dose prescribed according to a representative sample of prescriptions. The PDD can be determined from medical or pharmacy records. PDD should be related to the diagnosis on which the dosage is based. The PDD will give the average daily amount of a drug that is actually prescribed. When there is a substantial discrepancy between the PDD and the defined daily dose (DDD), it is important to take this into consideration when evaluating and interpreting drug utilization figures (15).

The use of DDDs as units of measurement offers better possibilities for comparisons than using quantities like number of tablets, number of packages etc. Use of DDD simplifies the evaluation of drug consumption over time. The DDDs are determined based on the international use of the substance, even though the indications and dosage vary worldwide. That is why DDD should be regarded as a technical measuring unit. DDD is indicated as the quantity of active substance and it expresses adult dosages (with the exception of some specific pediatric products). The most prescribed doses are not always the DDDs (15).

The sales figures are given as the number of DDDs/1000 inhabitants/day, and they are calculated using the following formula:

$$
\text { DDD per } 1000 \text { inhabitants per day }=\frac{D D D * 1000}{\text { Number of inhabitants } * 365 \text { days }}
$$

This offers an estimation of what proportion of the population that may receive a certain drug treatment (15). 


\subsection{Aim of the study}

The aim of this study is to describe and compare the use/sale of ADHD medicines in Norway and Serbia and to describe the possible differences in therapeutic approaches to ADHD in these two countries. This includes quality assessment of Serbian data as less is known about quality of that data than about the quality of Norwegian data. Since Norway has the Prescription Register, while Serbia does not, this assessment is needed in order to analyze the difference in use of ADHD medicines between Norway and Serbia in the best possible way. 


\section{Materials and Methods}

\subsection{Study design and population used in the study}

This study is a population-based epidemiologic study. The study has used sources of open wholesale and retail data as well as additional data collected from the Clinic for Neurology and Psychiatry for Children and Youth (CNPCY), in Belgrade, Serbia.

\subsection{Medications observed in the study}

Drugs that are observed in this study are defined by WHO as "Centrally acting sympathomimetics" and they are a subgroup of the Anatomical Therapeutic Chemical Classification System N06BA. The off-label drugs were not a part of this study since the data of off-label use is not accessible.

\subsection{Data collection}

\subsubsection{Data from Norway}

Data regarding the retail statistics and the study population is open data and was acquired from the Norwegian National Prescription Registry (NorPD). The data is anonymous and divided by age, gender and type of medicine (Table 11).

The NorPD contains data about dispensed drugs in Norway and it was established on 1st January 2004 at the Norwegian Institute of Public Health. 
The data used in this thesis is from 2004 until 2014. The reason for this is the fact that during this period a lot of new drugs were registered for ADHD treatment and there were changes in the diagnostic criteria. Also this period was chosen due to data availability because NorPD, like mentioned earlier, has been active since 2004.

Available data in the NorPD:

- Number of users, split by gender, age, county or health region

- Number of users per 1000 inhabitants (prevalence per 1000)

- Population base, distributed by gender, age, county or health region

- Turnover by value (pharmacy retail price in Norwegian kroner)

- Turnover by dosage (DDD - defined daily dosage)

A user is defined as a person who has had at least one prescription dispensed during the period in question.

In the database, it is possible to find the number of users of a particular drug/drug category per year in a defined population selection (gender, age, residence). Prevalence is defined as the number of users per 1000 inhabitants.

In the NorPD, every individual is allocated an encrypted unique identifier. This makes it possible to link drug use to individuals and follow their consumption over time, without knowing their identities. A person that has collected numerous prescriptions for the same drug is only counted once (72).

Information on trends in total drug sales, in other words wholesale data, can be found in the annual report "Drug Consumption in Norway" published by the Norwegian Institute of Public Health (NIPH). These statistics are based on sales of drugs from wholesalers to pharmacy/hospital and non-pharmacy outlets. This report also includes data about the DDD/1000/person for each drug and this was also used for this study $(73,74)$. 


\subsubsection{Data from Serbia}

Data regarding the wholesale statistics is open data and was acquired from the Agency for Medicines and Medical Devices of Serbia (ALIMS) (Table 11).

In accordance with the Law on Medicines and Medical Devices in Serbia, ALIMS is obliged to collect and process data on sale and consumption of drugs and publishes them annually (68). These publications contain health-economic and statistical indicators, as well as pharmaco-epidemiological indicators of drug use from which all kind of analysis can be made. The aim of these publications is to benefit the state institutions, but also all other participants in the Serbian drug market.

The data for the wholesale statistics from the use of medicines is observed for the period of 2007 until 2013. The reason for this is the fact that the only drug registered for the treatment of ADHD in Serbia, Concerta, has obtained the marketing authorization in 2006.

Data on the study population and retail data from Serbia is not easily accessible. In order to gather data about the ADHD population, one must have a registry of patients with ADHD. Such registry has not yet been established in Serbia. In Serbia there are several centers where one can be diagnosed with ADHD. The biggest center is the Clinic for Neurology and Psychiatry for Children and Youth in the capital Belgrade (CNPCY), which receives children from the whole country. Data for this study was gathered from this center in order to get additional information regarding the population of ADHD patients. It is gathered to show the Serbian ADHD population and to give some insight regarding the retail data in Serbia. This is just a sample since the gathered data is from one center only, but the data is representable because it is a big sample. The data collected from this center included gender, age, total number of ADHD cases, number of new cases and assigned therapy. Data was available for the period 2010-2015. The approval was obtained from the clinical committee of the center and the data was collected from the patient medical records. Data was collected by the center employees and it was in unidentifiable form. This data was used to calculate the ratio of ADHD patients out of all patients at the CNPCY, and the ratio of new ADHD cases per year out of all patients at the CNPCY. Data regarding the study population in Serbia is not open data and it was collected upon taking the initiative and contacting the psychiatrist in Serbia who wanted to take part in this study. This data is collected by email and mail correspondence. 
Table 11: Data sources for Norway and Serbia

\begin{tabular}{|l|l|l|}
\hline \multicolumn{3}{|c|}{ Data sources for Norway and Serbia } \\
\hline Country & Wholesale statistics data & Population data \\
\hline Norway & $\underline{\text { http://www.reseptregisteret.no/ }}$ & $\underline{\text { http://www.reseptregisteret.no/ }}$ \\
& $\underline{\text { http://www.legemiddelforbruk.no/english/ }}$ & http://www.alims.gov.rs/ciril?s=potrosnja \\
\hline Serbia & $\begin{array}{l}\text { Data acquired from the Clinic } \\
\text { for Neurology and Psychiatry } \\
\text { for Children and Youth } \\
\text { (CNPCY), Belgrade, Serbia. }\end{array}$ \\
\hline
\end{tabular}

\subsection{Quality assessment of drug sales data in Serbia}

In order to make comparison valid between two sets of data, it is necessary to do a quality assessment of the data in question. The aim is to identify whether there are quality issues present that would lead to wrong conclusions. The framework that was used in this study is the same as the framework used in the article about the data quality assessment of antibacterials in Iceland (75). The framework includes:

1) Completeness of registration - it refers to an indication of whether or not all data is available in the data resource. With registration that is complete, the statistical reports generated from this data will reflect an accurate status. Completeness is generally defined as the degree to which data represent reality from the required point in time.

2) Accuracy and degree of completeness of data - it refers to whether or not the data values stored for an object are correct. Data values have to have the right value and have to be shown in a consistent and unambiguous form. 
3) Size and coverage of the data source - discovering the size of the data source is a challenging problem since the size plays an important role in extracting data from the source while the coverage is a measure for the relative number of tuples (finite ordered lists of elements) that a source provides.

4) Data format - it is an important part of a communication process that the receiving device can determine what to do with the received data which is why all data has to be same of the same type. Otherwise, the data can exist in a complicated format making it practically useless.

5) Data accessibility, availability and cost - it refers to whether or not the statistical information is available to the user. It also implies if the information in question is easily accessible or not and what kind of medium is used when accessing the information. The information cost is an important aspect of data accessibility because if data is very costly that can prevent it from being used. Data can be accessible in a sense of existing in the right format but because of the charge it would be inaccessible to most. 


\section{Results}

\subsection{ADHD population in Norway from 2004-2014}

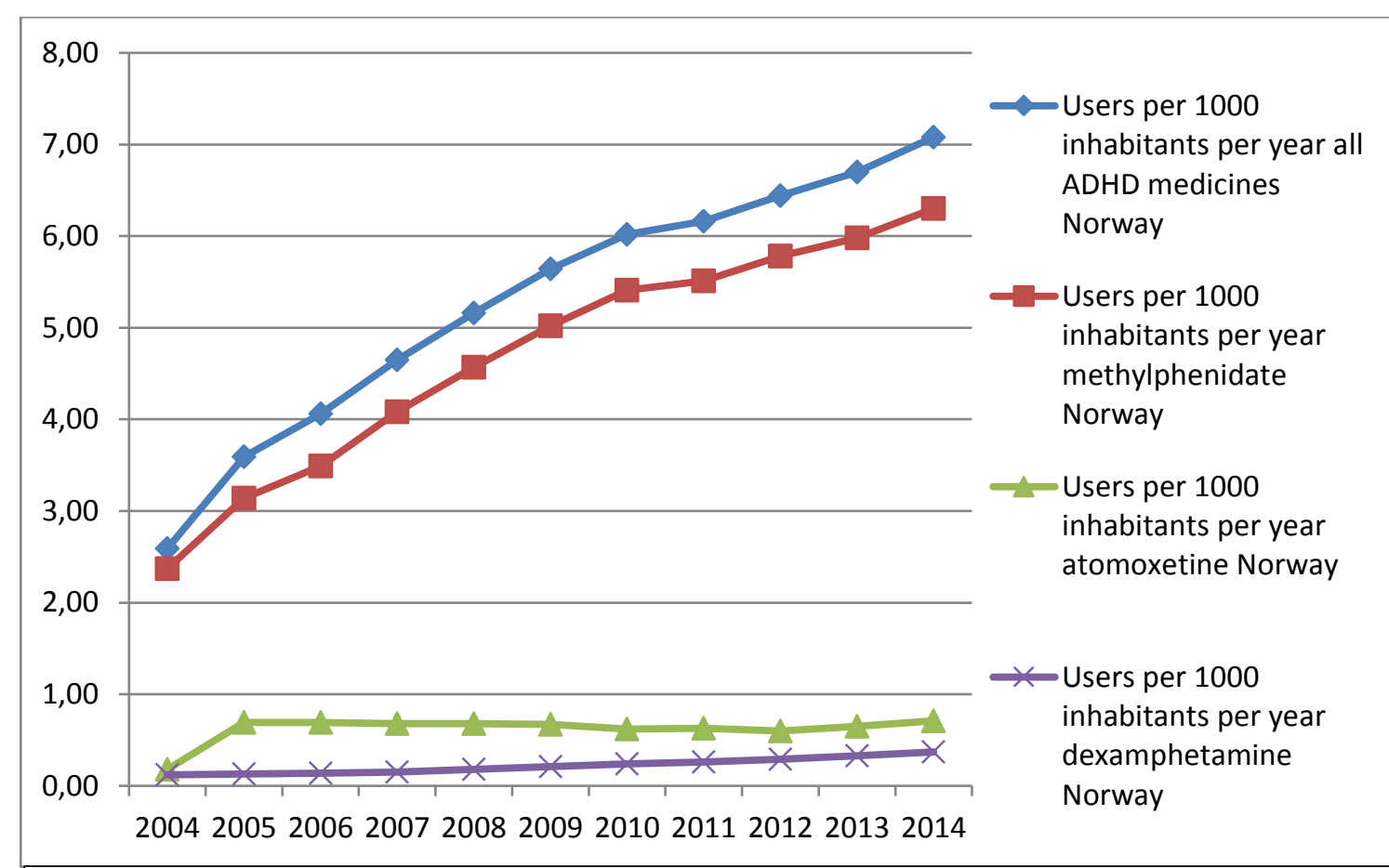

Figure 1: Number of ADHD medication users per 1000 inhabitants per year in Norway from 2004 until 2014 expressed as the total number of users of all ADHD drugs, and also divided into three main categories of ADHD medications: methylphenidate, atomoxetine and dexamphetamine. Data that was used to create this figure is available in Appendix 1.

Figure 1 shows that there has been an increase in the number of ADHD medication users during the ten-year period. Between 2004 and 2014 the increase in number of ADHD users was almost three times, from 2.59 per 1000 inhabitants in 2004 to 7.08 per 1000 inhabitants in 2014. The ADHD medications there are observed in this figure have the following ATC codes: N06BA01, N06BA02, N06BA04, N06BA09, N06BA12.

The figure also shows distribution of users of the three main categories of ADHD medications: methylphenidate (N06BA04), atomoxetine (N06BA09) and dexamphetamine (N06BA02). As can be seen there were most users of methylphenidate. 


\subsection{ADHD cases at the CNPCY in Belgrade, Serbia from 2010-2015}

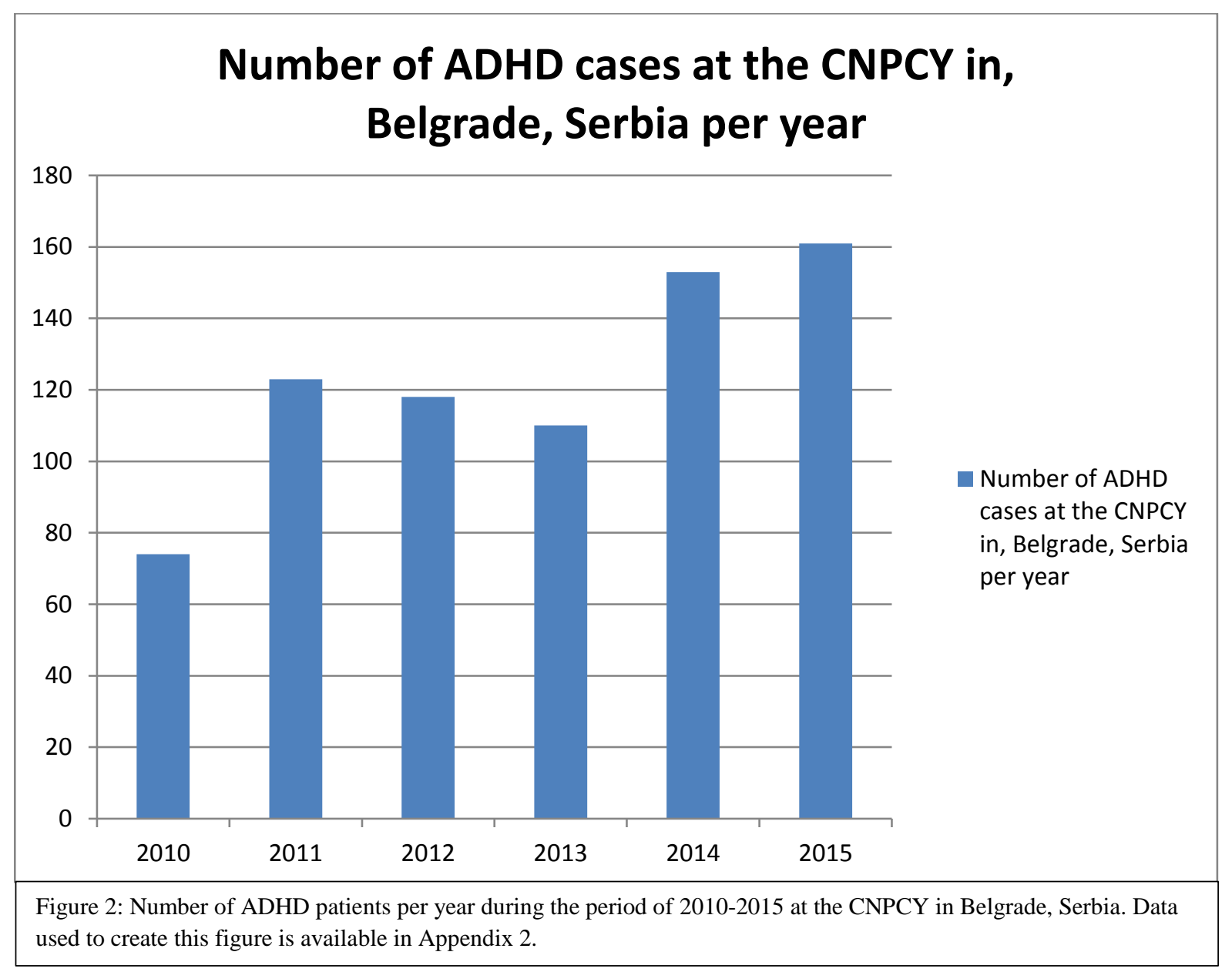

Figure 2 shows how many existing ADHD cases there were at the CNPCY in Belgrade from 2010 - 2015. Data shown in this figure includes all the patients who received ADHD diagnosis regardless of the treatment they received. Figure 3 shows the ratio of ADHD patients out of all patients at the CNPCY, and figure 4 shows the number of new ADHD cases per year. The ratio of ADHD patients and the number of new ADHD cases is calculated based on the number of ADHD cases per year at the CNPCY in Belgrade and the total number of psychiatric cases at that clinic. Figure 3 shoes an increase in the total number of ADHD cases over the years, while figure 4 shows a steep increase in the number of new cases in the beginning followed by a decrease and then an increase is observed again. 


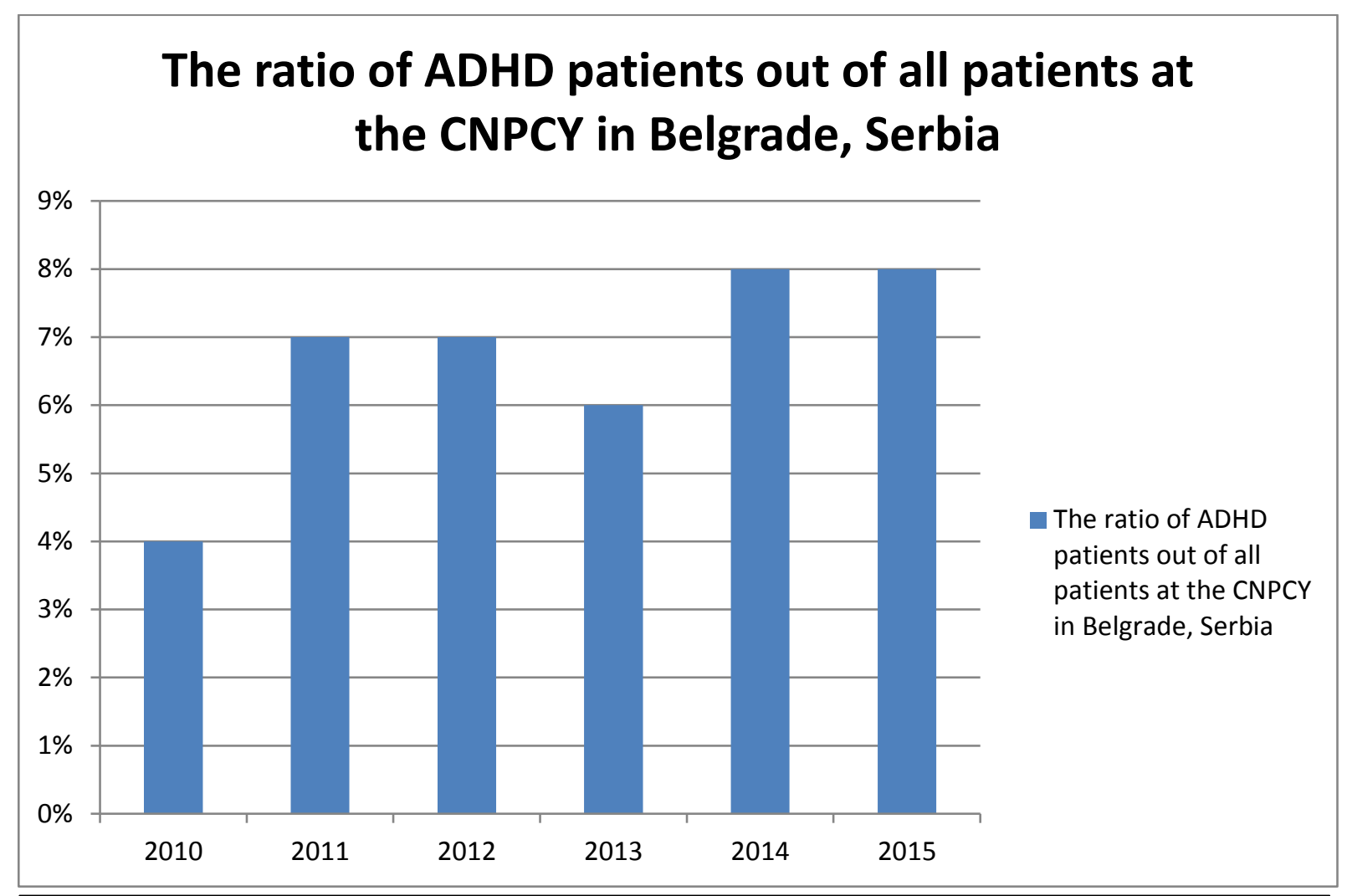

Figure 3: The ratio of ADHD patients out of all patients at the CNPCY in Belgrade, Serbia during the period of 20102015. Data used to create this figure is available in Appendix 2.

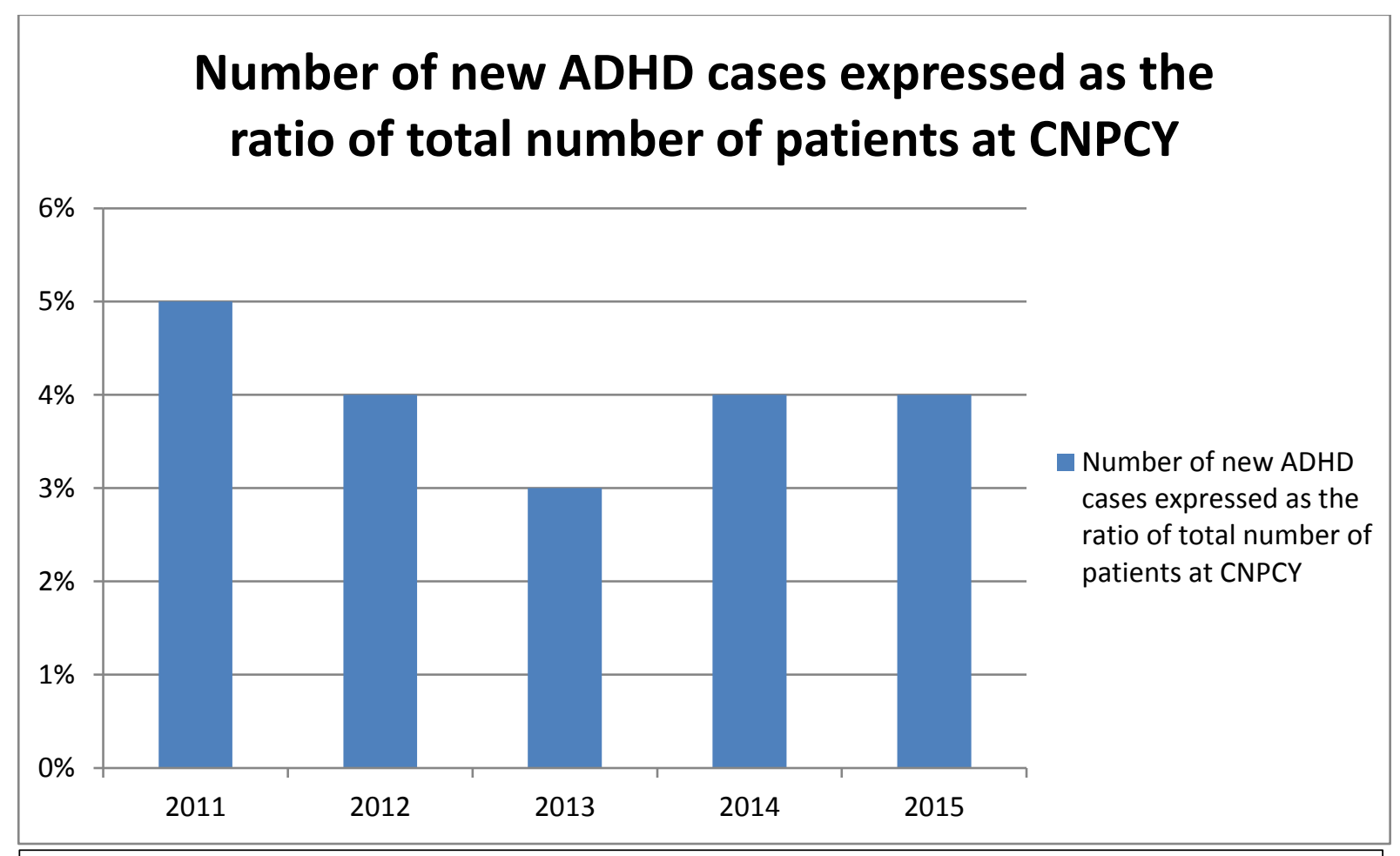

Figure 4: Number of new ADHD cases expressed as the ratio of total number of patients at CNPCY, Belgrade, Serbia during the period of 2010-2015. Data used to create this figure is available in Appendix 2. 


\subsection{Number of users of methylphenidate, dexamphetamine and atomoxetine during the period of 2004-2014}

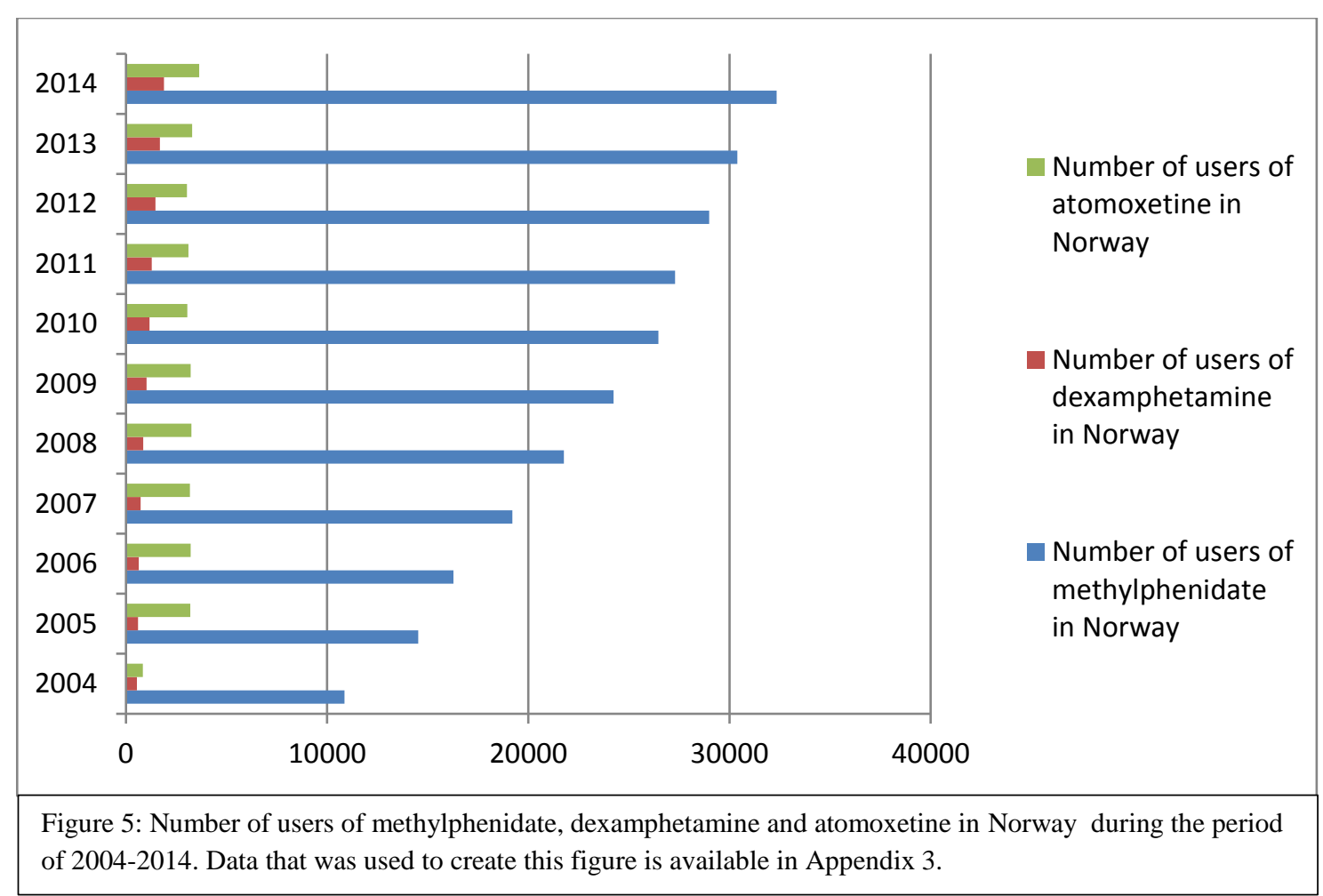

Figure 5 shows the total number of users per year of the three main drug treatments for ADHD: methylphenidate, dexamphetamine, atomoxetine during the period $2004-2014$ in Norway. The figure shows that the vast majority of users received methylphenidate for ADHD treatment. The number has increased three times in the ten-year period, from 10866 methylphenidate users in 2004, to 32344 in 2014. Atomoxetine is in second place, with 838 users in 2004 and 3635 users in 2014. The figure shows that after the initial increase in number of users of atomoxetine from 2004 (when it was registered) to 2005, the use was rather constant during the ten-year period. Dexamphetamine is in third place, with 545 prescriptions in 2004 and 1885 users in 2014. 


\subsection{Use of ADHD medicines in Norway during the period of 2004-2014 expressed in DDD/1000/day of methylphenidate, dexamphetamine and atomoxetine}

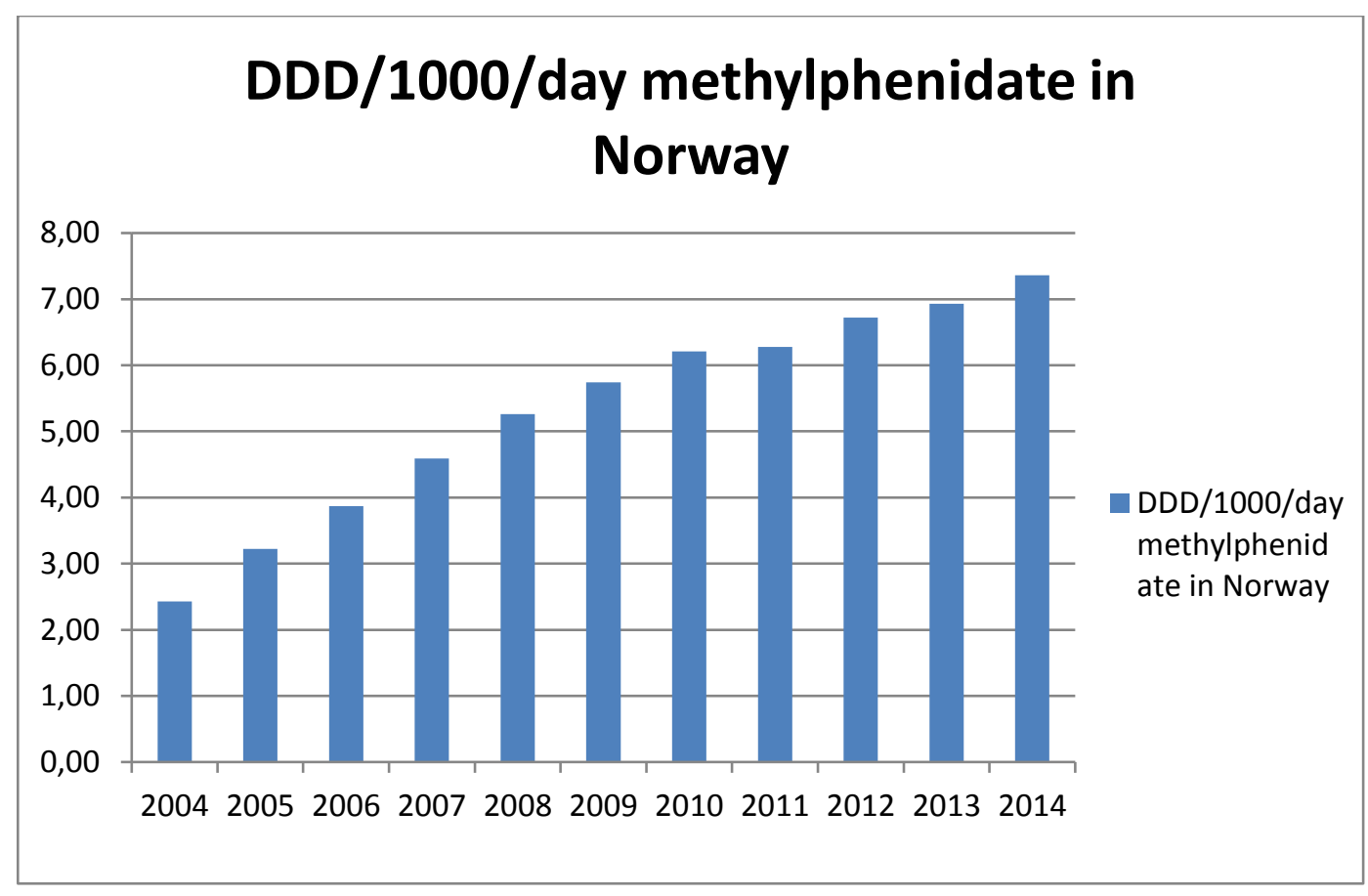

Figure 6: Use of methylphenidate in Norway expressed in DDD/1000/day during the period of 20042014. Data used to create this figure can be found in Appendix 4.

Figure 6 shows the use of methylphenidate in Norway. Use is shown as number of defined daily doses per 1000 inhabitants per day, and it includes all different methylphenidate formulations i.e. the ATC N06BA04: Ritalin, Concerta, Eqasym and Medikinet.

The figure shows an increase of use in the ten-year period. The DDD/1000/day for the year 2004 was 2.43 while the DDD/1000/day for the year 2014 was 7.36 , which means that the use when observed as DDD/1000/day was more than 3 times bigger in 2014 than 2004. 


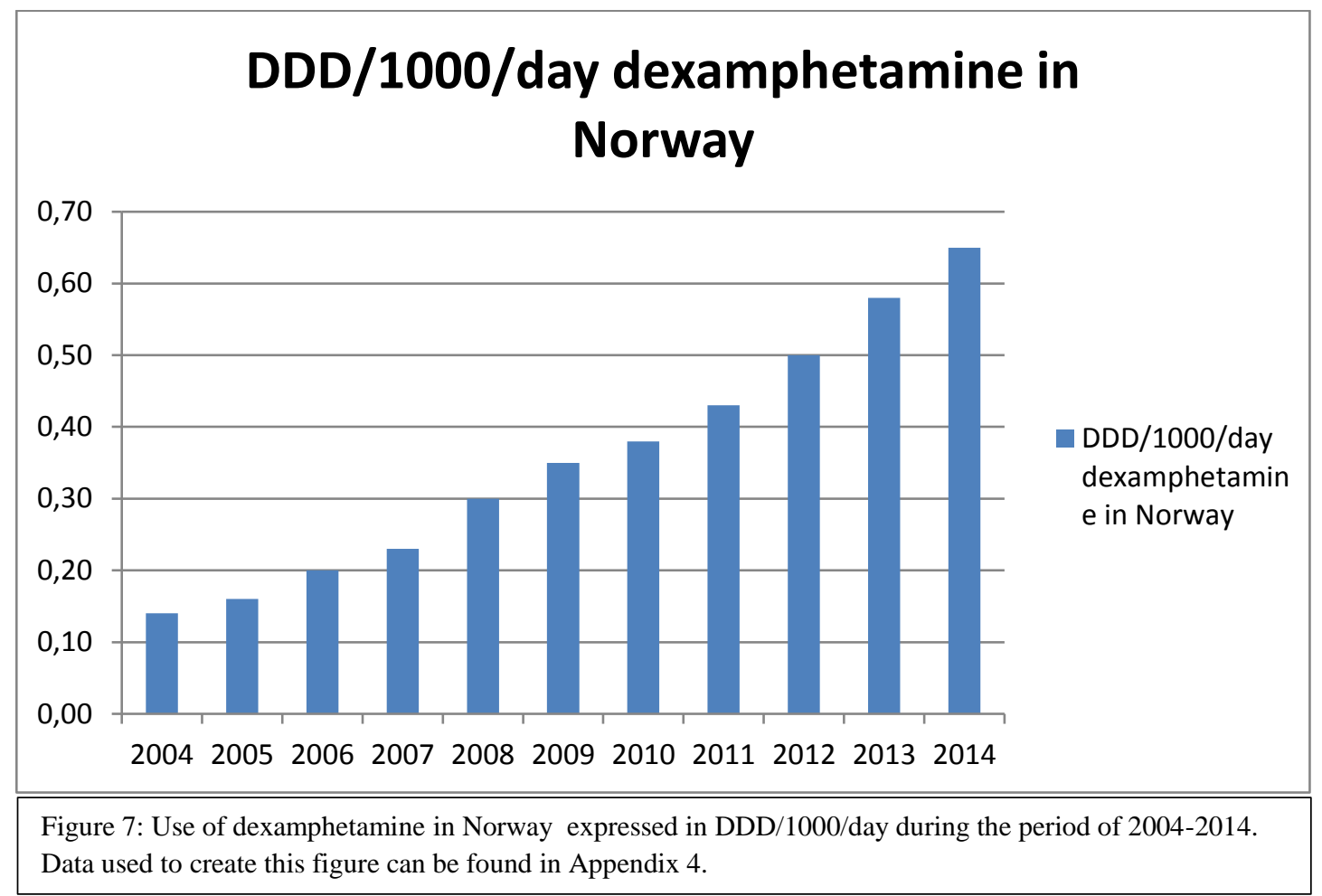

Figure 7 shows the use of dexamphetamine in Norway. Use is shown as number of defined daily doses per 1000 inhabitants per day. Figure shows an increase in use during the ten-year period. The DDD/1000/day for the year 2004 was 0.14 while the DDD/1000/day for the year 2014 was 0.65 , which means that the use hen observed as DDD/1000/day was almost 5 times bigger in 2014 than 2004.

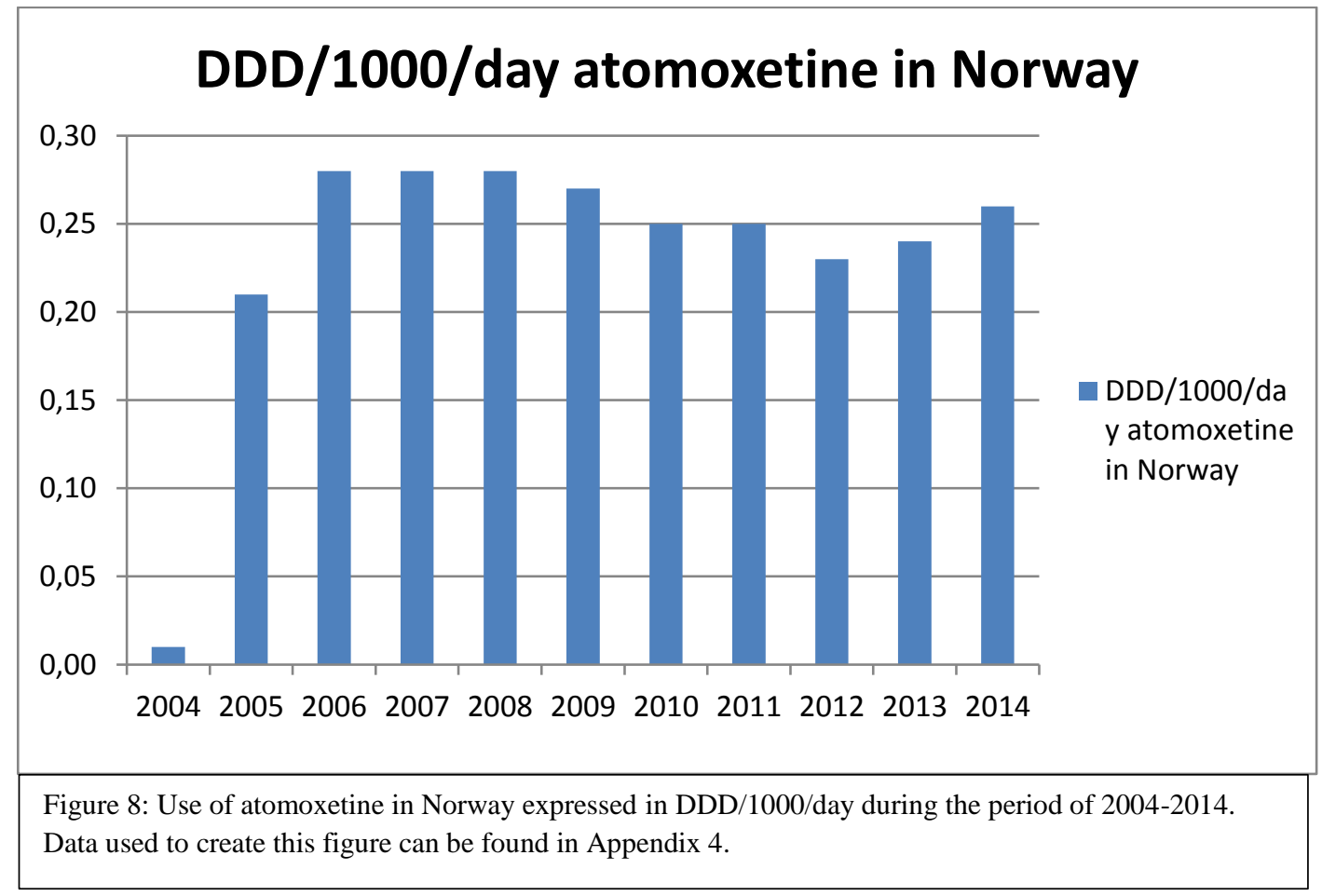


Figure 8 shows the use of atomoxetine in Norway. Use is shown as number of defined daily doses per 1000 inhabitants per day. Atomoxetine was registered in Norway in 2004, and after an initial increase in use, the use of atomoxetine was stable during the observed period 20042014.

\subsection{ADHD population in Norway and Serbia distributed by age and gender from 2010-2014}

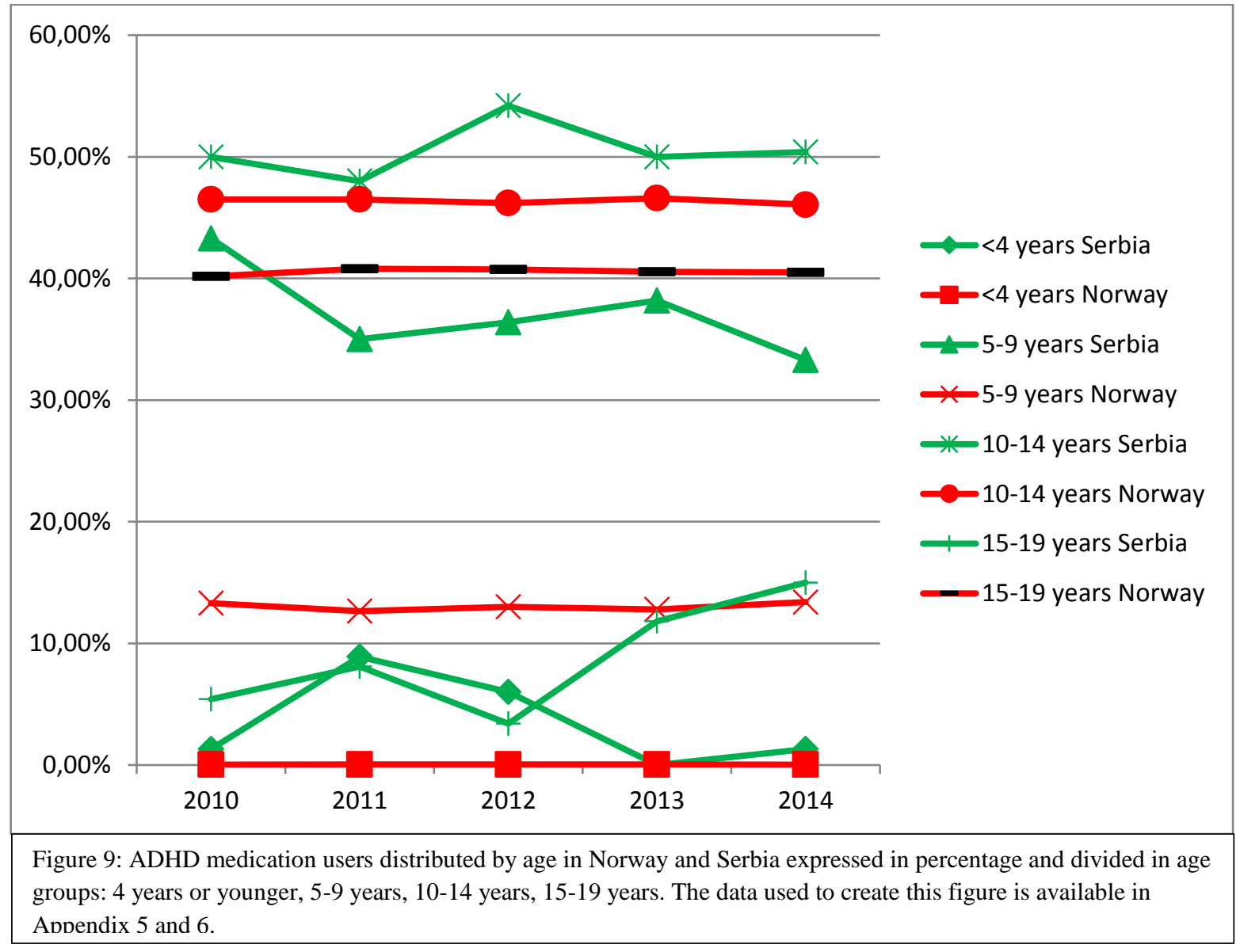

Figure 9 shows the distribution of ADHD medication users by age in Norway and Serbia from 2010 till 2014. The data is divided in 4 groups: 4 years or younger, 5-9 years, 10-14 years and 
15-19 years of age. What is not shown in the figure is the number of ADHD medication users in Norway who 20 years and older. This data can be found in appendix 6 .

The figure shows that the most ADHD medication users are in the age group 10-14 years in both countries, followed by 15-19 years age group in Norway and 5-9 years age group for both countries.

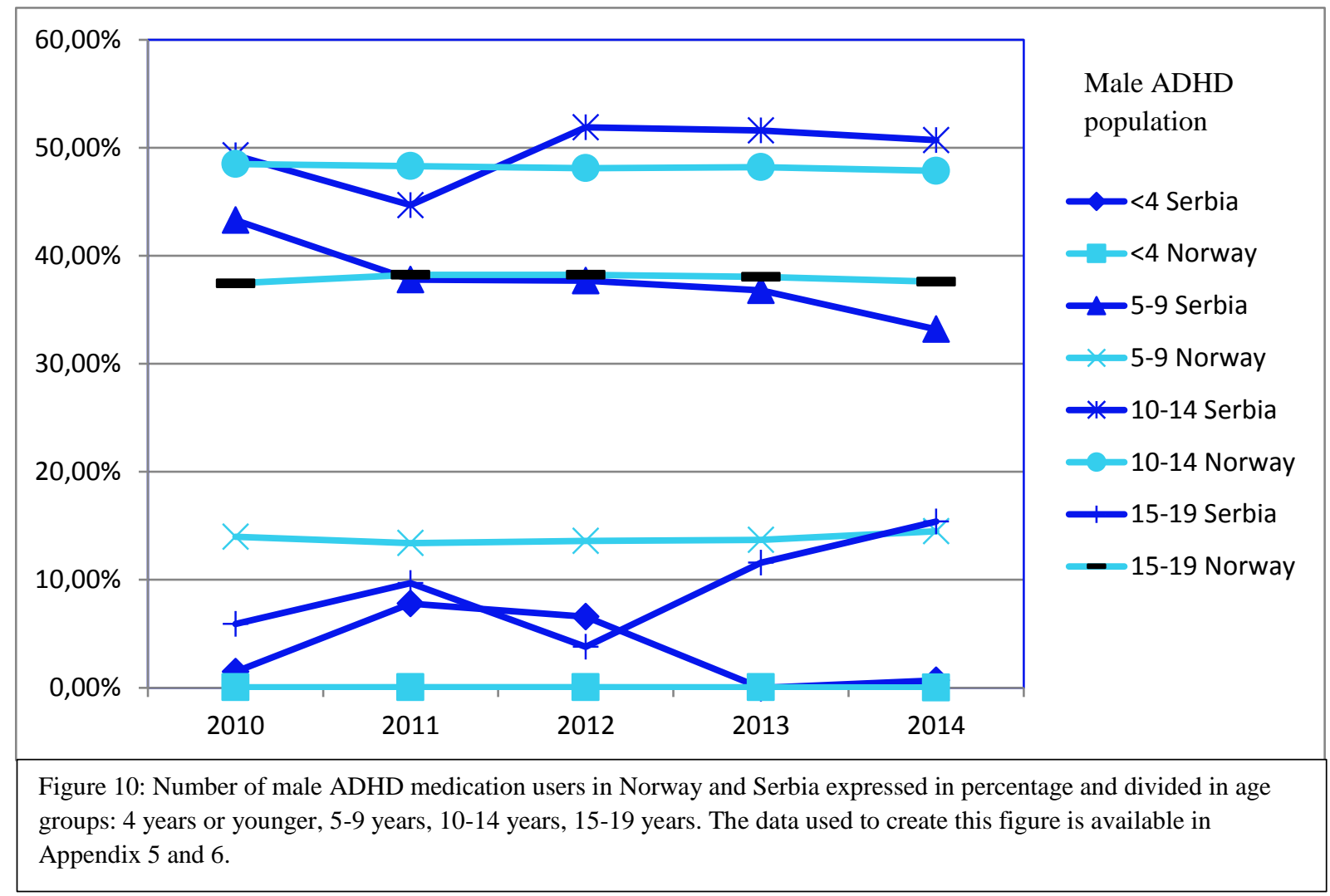

Figure 10 shows age distribution between male patients in Norway and Serbia expressed in percentage. In both countries most male patients were in the 10-14 years age group. It can also be observed that there more patients in Serbia in the age group 4 years or younger while there are almost none in Norway. The figure also shows that there are far more patients in the age groups 5-9 and 15-19 in Norway than there are in Serbia. 


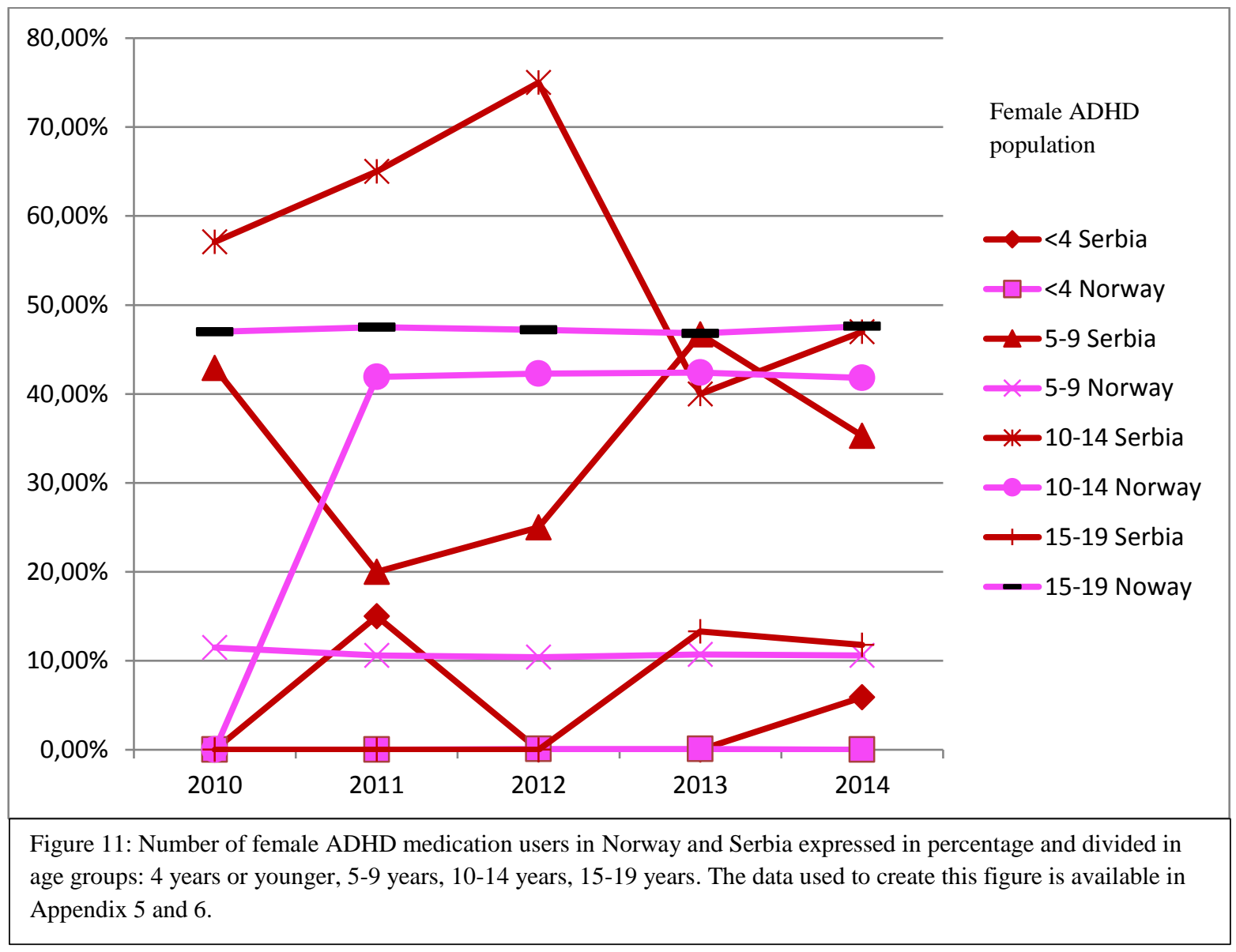

Figure 11 shows age distribution between female patients in Norway and Serbia expressed in percentage. Most of female patients were in 10-14 years age group in Serbia, while in Norway most female patients were in the 15-19 years age group, followed by 10-14 years.

Regarding the female population in Serbia, the figure clearly shows that the diagnosing of ADHD in different age groups hadn't been stable during the observed period. In the age groups 4 years or younger and 15-19 there were patients only in 2013 and 2014, while in other years in the observed period there were none. 


\subsection{ADHD population distributed by gender in Norway and Serbia from 2010-2014}

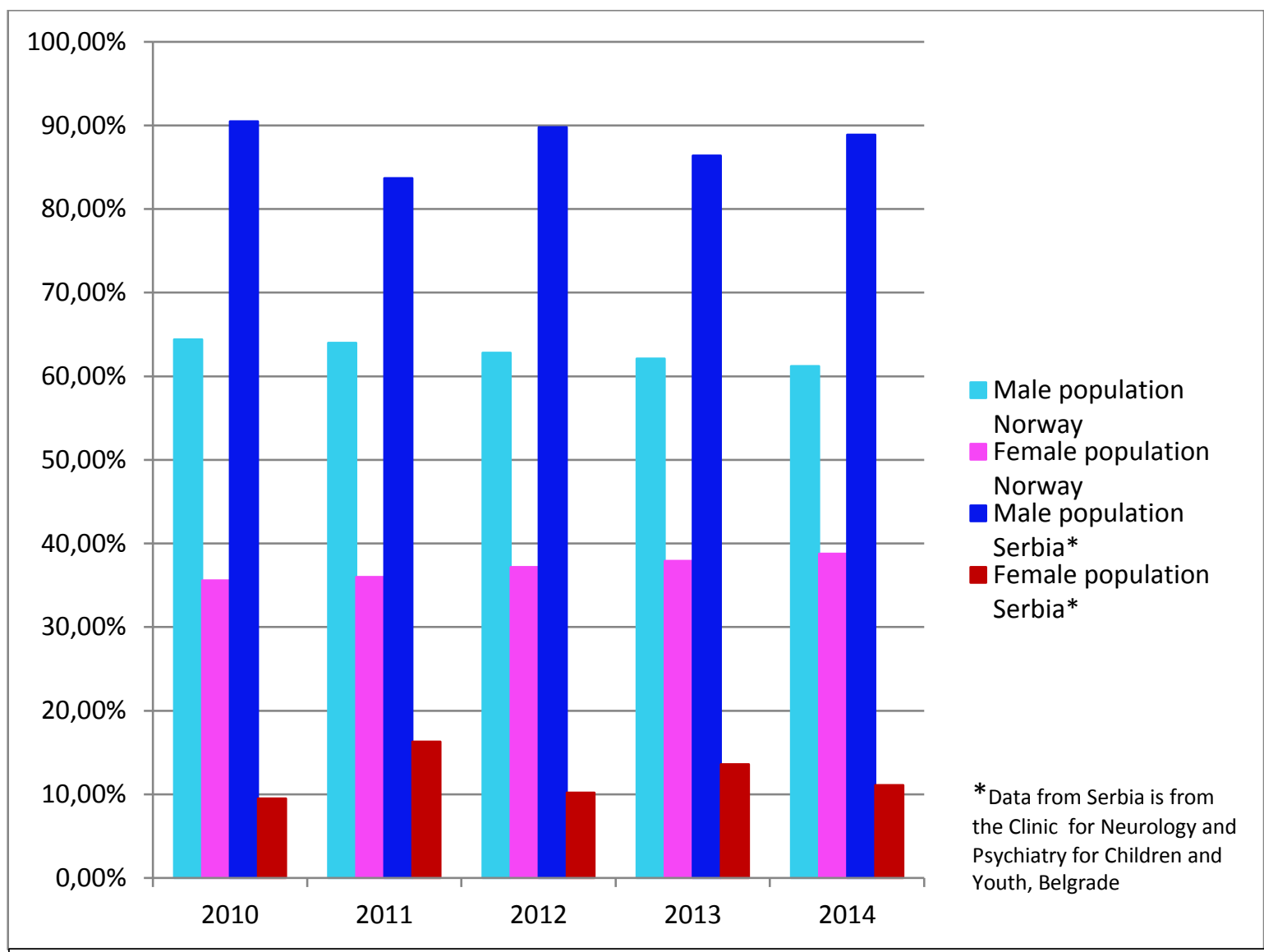

Figure 12: ADHD population from Norway and Serbia distributed by gender and expressed in percentage from 20102014. Data used for this figure can be found in Appendix 7 and 8.

Figure 12 shows how the ADHD medication users are divided by gender in both Norway and Serbia during the period of 2010-2014. It can be clearly seen that there are far more male users than female in both countries. The increase in the male population has been stable during the five-year period with tendencies toward decreasing, while a rather steep increase can be observed in the female population.

Data used to show gender distribution of ADHD cases from Serbia was gathered from the Clinic for Neurology and Psychiatry for Children and Youth, Belgrade, Serbia. The figure shows that there are significantly more male patients than female in Serbia. Male patients are on average 6 times more likely to get diagnosed with ADHD than females, as shown in the five-year period. 


\subsection{Assigned treatment for ADHD patients in Serbia in 2015}

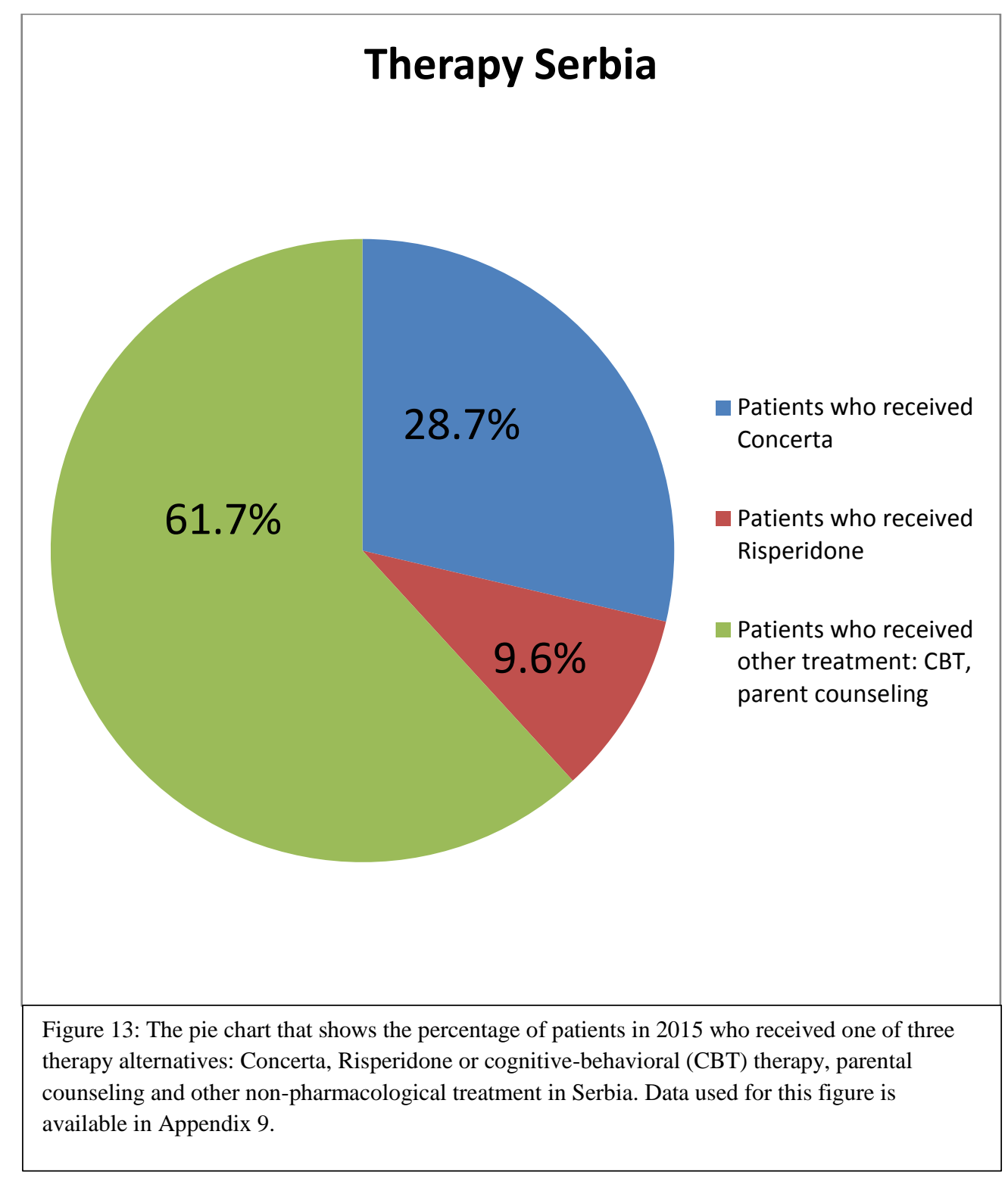

Figure 13 shows the distribution of different types of ADHD treatment in Serbia in 2015 at the CNPCY in Belgrade. Not all patients who were diagnosed with ADHD received pharmacological treatment. Of those $38 \%$ of patients who did receive pharmacological treatment, only $28.7 \%$ received Concerta while the rest received risperidone. The vast majority (61.7\%) of ADHD patients received cognitive-behavioral therapy, parental counseling and other non-pharmacological treatment rather than medical treatment only. 


\subsection{Distribution of different methylphenidate formulations in Norway during the period of 2010- 2014}

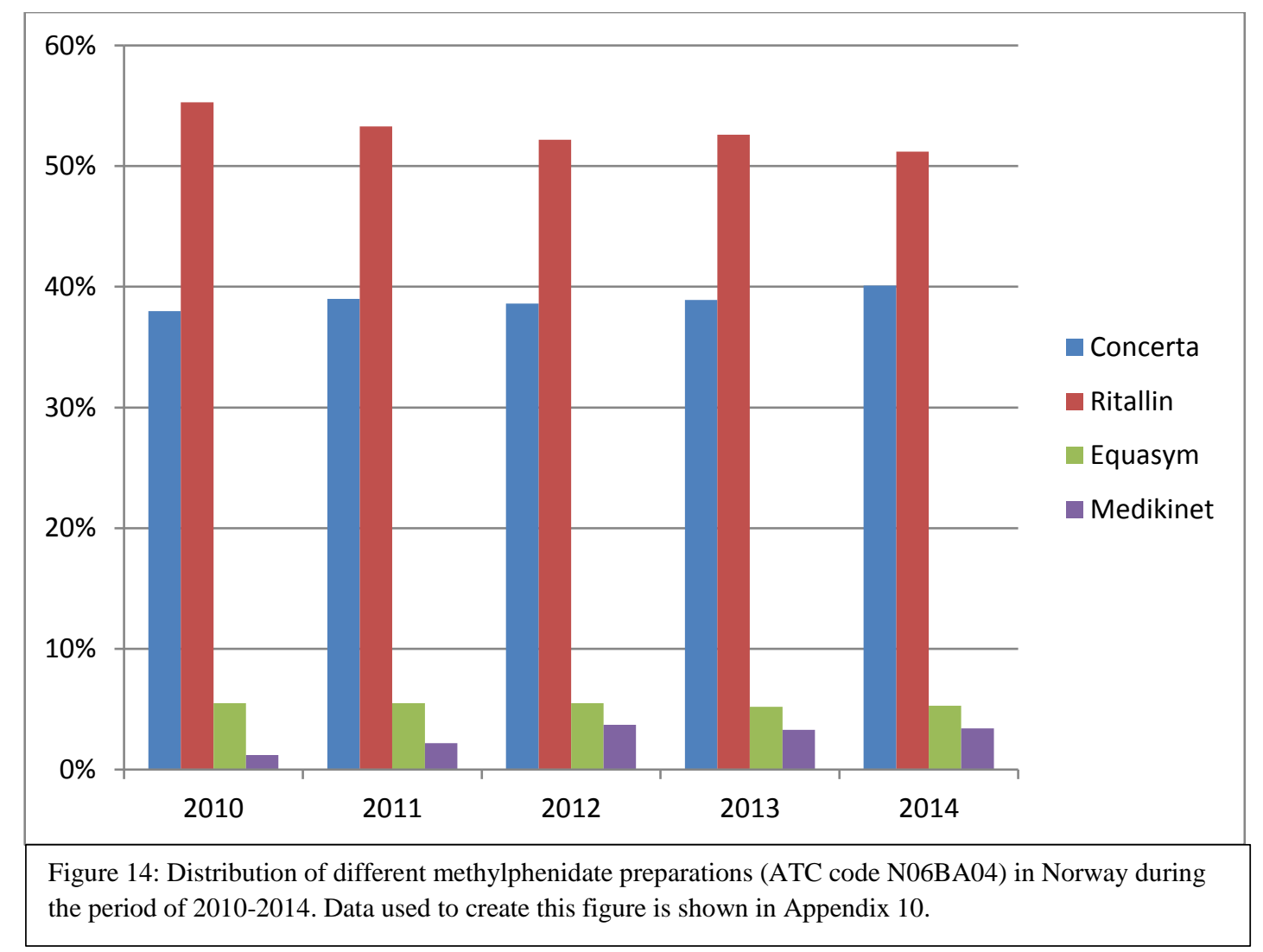

Figure 14 shows the use of different methylphenidate preparations within the ATC N06BA04: Ritalin, Concerta, Equasym and Medikinet during the period 2010-2014 expressed in percentage the number of users of the different methylphenidate preparations with regards to the total number of methylphenidate users for that year.

During these five years, most ADHD medication users who received methylphenidate as medical treatment used Ritalin.

Ritalin was closely followed by Concerta in second place. An increase in use of Concerta can be observed during the five year period. 


\subsection{Comparison of methylphenidate use in Norway and Serbia expressed in DDD/1000/day from 2007- 2013}
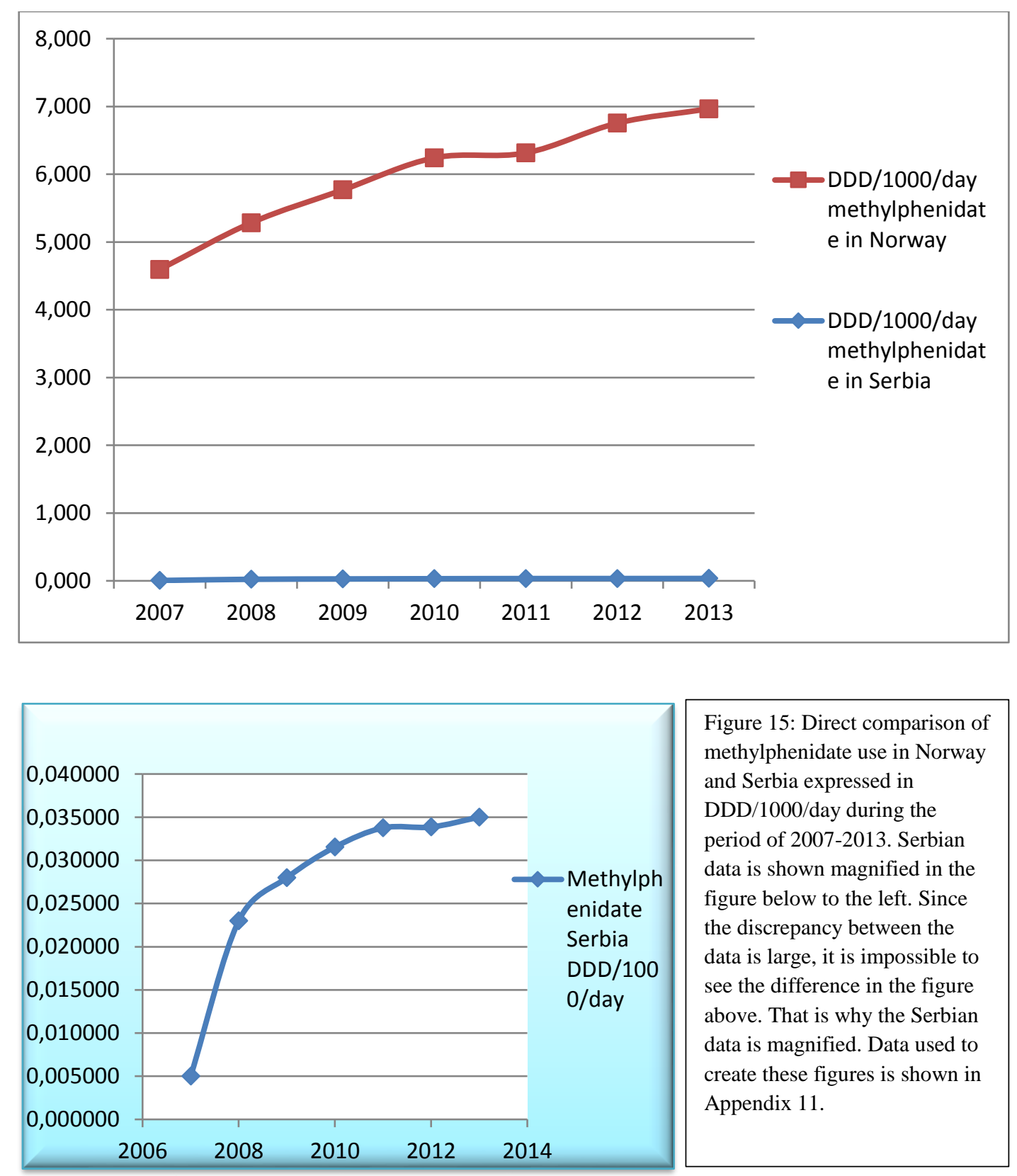
Figure 15 shows methylphenidate use during the period of 2007-2013 in Norway and Serbia. Use is expressed in daily defined dose (DDD) per 1000 inhabitants per day.

In Norway use of methylphenidate expressed in DDD/1000/day had increased steadily from 4.59 in 2007 up to 6.93 in 2013.

Use of methylphenidate in Serbia expressed in DDD/1000/day was the lowest in 2007 (0.005), afterwards a steep increase had occurred in 2008 (0.023). This increase had continued steadily until reaching a plateau. The end value for DDD/1000/day for the year 2013 was 0.035 , making it 7 times larger than the value of DDD/1000/day for the year 2007 . 


\subsection{Quality assessment of Serbian data}

\section{Completeness of registration}

As mentioned before in the introduction, Serbian narcotic control regulations are very strict. Both wholesalers and retailers and obliged to keep records of all the psychotropic substances they work with. These reports are sent to police and ALIMS on a regular basis. This shows that the wholesale and retail data regarding psychotropic medicines (i.e. methylphenidate) is thoroughly controlled from all sides and it is assumedly very complete, but the lack of access makes it impossible to conduct an accurate evaluation (68-71).

\section{Accuracy and degree of completeness of data}

Sales data is often used as a proxy for measure of drug consumption and this data includes sale from wholesaler to retailer i.e. from the distributers to pharmacies. When it comes to psychotropic medicines the wholesaler/distributer has the obligation to keep records regarding the sale of psychotropic substances (output), while the pharmacies/retailers have the obligation to keep records regarding the purchase of psychotropic substances (input). These records are afterwards sent to the ALIMS and to the police during the periodic controls (68, 69). Errors could be introduced when the reports are transferred from wholesalers/retailers to the ALIMS and when the reports are afterwards statistically processed by the Agency. The only way to detect this error would be to see both sets of reports. Since this was not possible, it can only be assumed that data is accurate and complete due to such strict rules regarding use and sale narcotics in Serbia (68-71).

\section{Size and coverage of the data source}

Regarding the coverage of data source, it is important to mention that according to the Healthcare law pharmacies are not obliged to have all types of registered medicines in stock at all time (76). The Healthcare law and the Ordinance on accreditation of health facilities (77) elaborate that the registered drugs have to be available to the public but it does not state that each and every pharmacy must have all ATC groups in stock. Patients/users are informed by their physician or pharmacist about pharmacies that have that particular drug in stock (if it is a kind of drug usually not found at all pharmacies). There are two types of drugs that are not 
found in every single pharmacy in Serbia. These are insulin products and psychotropic medicines. The reason for insulin not being available at every single pharmacy is because of special transport requirements (cold chain products), while there are several reasons for not having psychotropic medicines in stock. First of all, every pharmacy that has psychotropic medicines in stock must be registered at the police as a "pharmacy that has psychotropic controlled substances in stock" and only these pharmacies are allowed to order the psychotropic medicines from the wholesalers and dispense them to patients/users. Secondly, there usually has to be one person in charge of input/output control of psychotropic substances and for sending the reports periodically to police. It is usually a question of whether it is profitable for that particular pharmacy to have these drugs in stock, meaning whether or not they have patients who use these drugs.

With all this said, it is important to highlight that the coverage of the data source is complete when it comes to psychotropic medicines because these registered pharmacies are obligated to send periodical report to the police and to ALIMS for further statistical analysis. This data is not published, but can be acquired on demand from ALIMS.

\section{Data format}

The data format used in this study to compare the use of ADHD medicines in Norway and Serbia is primarily sales data from wholesaler to retail. DDD calculations down to package levels are made by ALIMS. This data is available electronically and easily accessible. Data used to assess ADHD population in Serbia was only available in paper and not easily accessible.

Discrepancies in data format could appear when there is a change in reimbursement system (that could lead to changes in prescription issuing) and when there is a change in DDD. The change in DDD could be made at different dates in different countries and that would create an error while comparing two different countries. Neither one is applicable for the use methylphenidate in Serbia during the observed period used in this study.

\section{Data accessibility, availability and cost}

It is not possible to do the quality analysis without accessing the data. It is important to state that data regarding ADHD population from Serbia is not accessible, and the data that is 
available regarding the study population is not complete data. However, the wholesale data that is available online from Serbia is easily accessible, complete and free of charge. 


\section{Discussion}

As mentioned earlier a number of different medications for ADHD treatment is registered in Norway, while in Serbia there is only one. In Norway the following medicines are used: Ritalin (both tablets and sustained-release capsules), Concerta (methylphenidate oros), Medikinet, Equasym (methylphenidate), Strattera (atomoxetine), Attentin (dexamphetamine) and Elvanse (lisdexamfetamine). In Serbia Concerta i.e. methylphenidate oros is the only registered drug used for ADHD, while all other drugs are not marketed.

Since methylphenidate is used the most in Norway and it is the only active substance registered in Serbia for ADHD treatment, the discussion will mostly be focused on the methylphenidate results.

It is obvious that the difference in use of ADHD medicines in Norway and Serbia is huge when observing the DDDs in these two countries. The use was on average 200 times larger in Norway than in Serbia during the observed period 2007-2013 as shown in Figure 15. There are several factors which could explain this big difference. First of all, there is only one ADHD drug registered in Serbia, while in Norway there are several. Secondly, there are a lot of adults in Norway who get pharmacological treatment for ADHD, while this is not the case in Serbia. The age distribution of the Serbian and Norway population should be considered. The population pyramid for both countries looks more like a turnip. In Serbia ADHD is mostly treated in children and adolescents and only a few if any adults get pharmacological treatment for ADHD. This could also be one of the factors that explain the low use of ADHD drugs in Serbia because in Norway adults are also getting the pharmacological therapy and thus increasing the use expressed in DDDs. It is important to emphasize that DDD is based on the average adult dose used for the main indication. If the dose refers to body weight, an adult is considered to weigh $70 \mathrm{~kg}$. Even pharmaceutical forms that are mainly intended for children are still assigned the DDD used for adults (15). This means that methylphenidate that is used only for children in Serbia for example, is nevertheless assigned a DDD for an adult person. Thirdly, the first (and only) ADHD drug in Serbia was registered in 2006, while in Norway this had happened a lot earlier. Ritalin tablets were the first to be registered and this happened in 2001, while Concerta capsules followed in 2003. Since it appeared on the 
market in Serbia, a large increase in prescription has been observed, but the drug is still viewed in Serbia as rather new. Finally, in Serbia there are no official guidelines for ADHD at this time, and even the condition alone can be considered as rather new. This means that a lot of teachers and parents are not aware of the condition and therefore cannot always recognize the symptoms. Since no official tools for diagnosing ADHD are available, parent and teacher reporting is very important. In short there are a lot of factors which could influence the potential under-diagnose of ADHD in Serbia, and by that could explain the vast difference observed between Norway and Serbia.

On the other hand, trends regarding the increase in use per year were surprisingly similar in both countries. The observed growth per year for both Norway and Serbia was approximately $10 \%$ when expressed in DDD/1000 inhabitants/day.

There are also other explanations for the increase in use and diagnose of ADHD in Norway primarily, but also in Serbia. First and foremost, public awareness regarding ADHD has increased as well as the availability of pharmacological treatment. Even in Serbia this can be seen since 2007 when Concerta obtained marketing authorization. On the other hand, the increase in use of ADHD drugs can also be attributable to misuse. A study has been conducted in USA regarding ADHD medication abuse by teenagers (78). The conclusion of this study was that there was a large increase in misuse and that this can suggest a rising problem with ADHD stimulant medication abuse. Finally, there have been a lot of speculations regarding the potential over-diagnosis of ADHD. When it comes to public perceptions and media coverage of ADHD, over-diagnosis controversy usually comes up. A study has been conducted whose aim was to evaluate the evidence for and against overdiagnosis (79). This study has found that there was not enough evidence to conclude that ADHD is systematically over-diagnosed. If the public perceives that over-diagnosis of ADHD is a larger problem than under-diagnosis, then this could explain why there are so few ADHD cases in some countries like Serbia. If the general public feels like ADHD is over-diagnosed, then they will perceive any number of ADHD cases as too big, and they will also question the ADHD diagnosis itself as whether or not it is a legitimate condition. If this happens, then the threshold for the number of ADHD cases in that specific population will be lower than it should be. Oppositely, if the public considers over-diagnosing not to be a problem, then the threshold for the number of ADHD cases will be higher than it should be. When looking at the numbers shown in this project one might question whether or not ADHD is over- 
diagnosed in Norway and/or under-diagnosed in Serbia. At this point it is not easy to prove that, since there is no official test for ADHD and diagnostic criteria can vary from country to country. The potential under-diagnosis in Serbia is more likely to explain some of the difference especially since adults in general are not getting treated for ADHD in Serbia and Serbian public is not that concerned with ADHD.

It is also important to emphasize that not all western countries have a "high" ADHD prevalence (high in comparison to Serbia). ADHD prevalence in France is lower than in most other western countries. The same goes for the use in methylphenidate in France, it is low and it coincides with the use of methylphenidate in Serbia found in this study (80). A study was conducted regarding the prevalence and methylphenidate use in children and adolescents in France (81). The following conclusions were found. Increase in methylphenidate use by children and adolescents in France in the 10 year-period was observed, but the prevalence of ADHD was shown to be lower than in other western countries. They stated that the possible reasons for this were the under-diagnosis of ADHD and/or the reluctance of the physicians to prescribe pharmacological treatment to affected patients (81). Why are the numbers regarding the use of methylphenidate so similar in France and in Serbia, and so different from Norway? This can be explained by the fact that methylphenidate has restrictive conditions of prescription and delivery in France that are almost the same as in Serbia. It is listed as "narcotics" and because of that the prescription is limited to a 28-day period. The treatment has to be initiated in a hospital by a specialist. The prescription can be refilled by any other physician, but they cannot change the initially prescribed dosage or quantity. This only shows that the prescribing and utilization patterns are very similar between France and Serbia.

Western countries who do have a "high" ADHD prevalence (high in comparison to Serbia) are Germany, UK and USA and these rates correspond to Norwegian rates. Rates of ADHD treatment in the UK and United States when observed in DDDs have increased since the 1970s. This is explained due to changes in how the condition is diagnosed and with the fact that more people were willing to get treated with medications (82). An evaluation in Germany in 2008 that monitored 14,836 children of age 3-17 showed that $4.8 \%$ of the participants had an ADHD diagnosis and were getting medical treatment (83). In the United States the number of children with ADHD diagnosis was 95 per 1,000 in 2007 (82) and 110 per 1,000 in 2011 (82). 
There are far more male users of ADHD medications than female in both Norway and Serbia. The increase of male users has been rather constant in both countries during the observed period, while a steep increase of female users was observed. In both Norway and Serbia, the total number of boys had increased two times in the observed period. In Norway the number of girls had increased five times in the observed period. In Serbia the biggest increase is observed in 2015 were the number of girls with ADHD had doubled from the previous year. The total increase in Serbia for girls was five times, the same as in Norway, in the observed period.

The fact that this study found that there are more male patients than female is consistent with the findings of other studies and with the overall estimation that male-female ration is in the range from 2:1 till 9:1 (85). In Germany in a study conducted in 2008 it was shown in the observed specimen that $7.9 \%$ of all boys and $1.8 \%$ of all girls had ADHD (82). In the UK according to statistical data from 2003, 3.6\% of boys and less than $1 \%$ girls had ADHD (84). In the United States the frequency of ADHD diagnosis is $10 \%$ in boys and $4 \%$ in girls (82).

There are several factors that could explain this difference. One of the possible reasons could be the fact that girls are not associated with so many comorbidities like conduct disorders, bipolar disorder and depression found in boys which may be the reason why more boys seek psychiatric help than girls do $(85,86)$. Other explanations are like mentioned earlier in the introduction, girls with ADHD tend to be less impulsive, less aggressive and less hyperactive compared to boys with ADHD (14), while having great difficulties in sustaining attention. This can make it difficult to diagnose girls.

While analyzing the age distribution in both Norway and Serbia, it is obvious that most ADHD medication users are in the age group 10 to 14 years. There were mostly boys that received pharmacological treatment in this age group. All this is in accordance with other studies that were conducted regarding ADHD prevalence in different age groups. An epidemiological study regarding use ADHD medicines in Nordic countries has also shown that men in the age group 10-14 years had the highest use frequency and consumption of ADHD medicines (87). Another study that analyzed the use of psychotropic substances in children had been conducted in the Netherlands (88). This study has shown that stimulants were the most widely used psychotropic agents among 0 to 19 year olds and among boys in this age group. They also found that more girls were getting treated and that the duration of stimulant treatment increased as well (88). 
In Serbia however, no data regarding the use of stimulants in adults is available, so no comparison between Norway and Serbia is possible in that age group. On the other hand, in Norway, a lot of ADHD medication users are in the age group 20 years and older, in addition to other countries like USA (89).

Current data regarding the ADHD prevalence worldwide suggests that there is a higher rate of ADHD cases in children in the United States than in Africa and the Middle East (90). This is explained with the fact that different diagnostic methods are used in different parts of the world (90). It is suggested that if the same diagnostic methods were to be used everywhere in the world, the prevalence rates would be nearly the same between countries (90). It is also suggested that due to changes in the diagnostic criteria from the DSM-4 the DSM-5 in 2013 the number of people with ADHD, especially among adults, will increase (91).

A great deal of attention was paid to data quality from Serbia. At first glance one could question the quality, but after detailed analysis this project has found that the data is not of bad quality, it is just less accessible and of less coverage than Norwegian data. Wholesale data from Serbia regarding ADHD medications is assessed to be complete and of good quality because of the fact that narcotic drugs are thoroughly monitored in Serbia from all sides.

The biggest quality issue with Serbian data is the acquirement of data regarding the Serbian population affected with ADHD. At this point it is not possible to determine the prevalence and incidence of ADHD since there is no prescription registry in Serbia. With a prescription registry it would be possible to determine the number of ADHD medication users and the number of new users. These numbers would reflect to some extend the prevalence and incidence of ADHD but not fully because a lot of patients (for example adult patients) are receiving cognitive-behavioral therapy only. There is no data regarding ADHD prevalence or incidence available in literature either. Other studies from Serbia regarding ADHD were also based only on samples of patients with ADHD.

Second quality issue regarding Serbian data is the unavailability of data for off-label use of Risperidone and Clonidine in ADHD treatment. At this point it is not possible to differentiate use of Risperidone on indication versus off-label, while Clonidine has lost its marketing authorization in Serbia and no data regarding its use is available at this point. A study conducted in USA had shown that psychotropic medications are available online with or without a prescription (92). The study concluded that it is possible to acquire medication from 
online pharmacies without a prescription. Hypothetically, this could also be the case in Serbia regarding Clonidine first and foremost, but no data regarding this was available.

It is also important to mention that like in many other countries the biggest problem for providing treatment of psychiatric disorders is the fact that there's a limited treatment available in primary care (93). In order to get diagnosed a person would have to travel to one of the four larger cities in Serbia as the Serbian psychiatry is mostly hospital-based and therefore not easily accessible. This could be also one of the reasons for possible underdiagnosis of ADHD is Serbia.

\section{Strengths}

This study is of great importance for Serbia, because no other study provided data for the ADHD population and ADHD treatment in Serbia. The only other study that came up during the literature search regarding ADHD in Serbia, was a study conducted in Novi Sad, the second largest city in Serbia where ADHD can be diagnosed. This study was conducted in order to examine rates and distribution of emotional and behavioral problems (including ADHD) among 4 to 6-year-old children in the Serbia (94). In this study children's parents who participated were asked to complete the questionnaires and they were asked to consider their child's behavior "now or within the past 2 months" (94). This is the only other study conducted with any mention of ADHD population and prevalence among young children in Serbia, although they used different methods in their study.

\section{Limitations}

As mentioned before, in Serbia only Concerta is available as a registered drug used to treat ADHD while in Norway various drugs from different manufactures are marketed. This makes comparison difficult.

It is also important to highlight that no official data regarding the ADHD population, prevalence or incidence in Serbia was available. ADHD medications could have been used as a proxy for the prevalence and incidence, but that has not always been a good indicator, especially not in this case because in Serbia a lot of patients do not receive pharmacological treatment. This is why patients at the CNPCY in Belgrade, Serbia were used in this study in order to describe the ADHD population to some extent. However, this is just a sample used to describe Serbian ADHD population, this is not the prevalence and the real Serbian ADHD 
population can only be bigger, when all other patients that were never treated at this clinic are included.

In Norway the statistic on sales is endorsed by the national register of prescription and it's easily accessible. In Serbia it is possible to find statistical data on a wholesale level and it is much more detailed, but not as easily accessible as in Norway. Serbian data regarding the ADHD population is accessible only in paper form and it is not easily accessible.

\section{Future recommendations}

First and foremost, further exploration of ADHD prevalence in Serbia is necessary so as to get the whole picture of the Serbian ADHD population. Secondly, it is also important to evaluate the off-label use of ADHD medications in Serbia. Finally, it would be recommended to explore additionally ADHD treatment in Norway and Serbia in order to offer explanations for such dissimilarities found in this study and whether or not ADHD is over-diagnosed in Norway and/or under-diagnosed in Serbia. 


\section{Conclusion}

Pharmacological treatment approaches to ADHD in Norway and Serbia are different. While in Norway both atomoxetine and dexamphetamine are used in addition to methylphenidate, in Serbia only methylphenidate is registered for ADHD treatment. Use of methylphenidate in Norway is approximately 200 times bigger than in Serbia when expressed in DDD/1000 inhabitants/day. In Serbia ADHD is still regarded as a childhood disease, while in Norway adults are also getting treated. Both countries have in common the fact that ADHD is more prevalent in boys and the age group 10 to 14 years stands out as the age group with the highest rate of methylphenidate consumption and ADHD diagnosis. Regarding data quality from Serbia, the study has found that Serbian data is of good quality but not easily accessible. Further research is needed to identify ADHD prevalence in Serbia, also to determine whether or not ADHD is over-diagnosed in Norway and/or under-diagnosed in Serbia because this could be a possible explanation for such discrepancy between Norway and Serbia. It is also important to establish how big of a role do different genetic, cultural and diagnostic factors play in ADHD. 


\section{References}

(1) National Institute of Mental Health (2008). Attention Deficit Hyperactivity Disorder (NIH Publication No. 08-3572). Accessed on May 4 ${ }^{\text {th }}, 2016$. Available online: http://www.nimh.nih.gov/health/publications/attention-deficit-hyperactivitydisorder/adhd_booklet.pdf

(2) Asherson P, Chen W, Craddock B, Taylor E. Adult attention-deficit hyperactivity disorder: recognition and treatment in general adult psychiatry. Br J Psychiatry. 2007 Jan; 190:4-5.

(3) World Health Organization. The ICD- 10 classification of mental and behavioural disorders: clinical descriptions and diagnostic guidelines. Geneva, 1992. Accessed on May $4^{\text {th }}$ 2016. Available online: http://www.who.int/classifications/icd/en/bluebook.pdf

(4) American Psychiatric Association: Diagnostic and Statistical Manual of Mental Disorders, 5th edition. Arlington, VA., American Psychiatric Association, 2013. p. 50-65.

(5) Swanson JM, Kinsbourne M, Nigg J, Lanphear B, Stefanatos GA, Volkow N, Taylor E, Casey BJ, Castellanos FX, Wadhwa PD. Etiologic subtypes of attentiondeficit/hyperactivity disorder: brain imaging, molecular genetic and environmental factors and the dopamine hypothesis. Neuropsychol Rev 2007; 17(1):39-59.

(6) Volkow ND, Wang GJ, Newcorn J, Telang F, Solanto MV, Fowler JS, Logan J, Ma Y, Schulz K, Pradhan K, Wong C, Swanson JM. Depressed dopamine activity in caudate and preliminary evidence of limbic involvement in adults with attention- deficit/ hyperactivity disorder. Arch Gen Psychiatry. 2007; 64(8): 932-940.

(7) Polanczyk G, De Lima MS, Horta BL, Biederman J, Rohde LA. The worldwide prevalence of ADHD: a systematic review and metaregression analysis. Am J Psychiatry. 2007; 164:942-8.

(8) Fayyad J, De Graaf R, Kessler R, Alonso J, Angermeyer M, Demyttenaere K, De Girolamo G, Haro JM, Karam EG, Lara C, Lépine JP, Ormel J, Posada-Villa J, Zaslavsky AM, Jin R. Cross-national prevalence and correlates of adult attention-deficit hyperactivity disorder. Br J Psychiatry. 2007 May; 190:402-9. 
(9) Taylor E, Döpfner M, Sergeant J, Asherson P, Banaschewski T, Buitelaar J, Coghill D, Danckaerts M, Rothenberger A, Sonuga-Barke E, Steinhausen HC, Zuddas A. European clinical guidelines for hyperkinetic disorder -- first upgrade. Eur Child Adolesc Psychiatry. 2004;13 Suppl 1: I7-30. Asherson P1, Adamou M, Bolea B, Muller U, Morua SD, Pitts M, Thome J, Young S. Is ADHD a valid diagnosis in adults? Yes. BMJ. 2010 Mar 26;340:c549.

(11) Zoëga H, Furu K, Halldórsson M, Thomsen PH, Sourander A, Martikainen JE.; Use of ADHD drugs in the Nordic countries: a population-based comparison study; Acta Psychiatr Scand 2011: 123: 360-367 Barkley R, Attention-Deficit Hyperactivity Disorder: A Handbook for Diagnosis and Treatment, Third Edition, The Guilford Press: New York. 2006. J Can Acad Child Adolesc Psychiatry. 2008 Feb; 17(1): 31-33. Gaub M, Carlson CL. Gender differences in ADHD: a meta-analysis and critical review. J Am Acad Child Adolesc Psychiatry. 1997 Aug;36(8):1036-45. Berry CA, Shaywitz SE, Shaywitz BA. Girls with attention deficit disorder: a silent minority? A report on behavioral and cognitive characteristics. Pediatrics. 1985 Nov;76(5):801-9. WHO Collaborating Centre for Drug Statistics Methodology (WHOCC): DDD Definition and general considerations. Accessed on June $7^{\text {th }}$ 2016. Available from: http://www.whocc.no/ddd/definition_and_general_considera/ Dusan Kolar, Amanda Keller, Maria Golfinopoulos, Lucy Cumyn, Cassidy Syer, and Lily Hechtman. Treatment of adults with attention-deficit/hyperactivity disorder. Neuropsychiatr Dis Treat. 2008 Apr; 4(2): 389-403. Concerta $18 \mathrm{mg}$ and $36 \mathrm{mg}$, prolonged release tablets - Summary of Product Characteristics for Serbia, accessed on June $7^{\text {th }}$ 2016. Website of the Serbia Drug Agency. Available from: http://www.alims.gov.rs/ciril/files/lekovi/pil/515-01-0464-11-001.pdf Diagnostikk i barne- og ungdomspsykiatri. Den norske legeforening: Norsk barne- og ungdomspsykiatrisk forening, 2014. Accessed on July 15th 2016. Available 
from http://legeforeningen.no/Fagmed/Norsk-barne--og-ungdomspsykiatrisk-

forening/Faglig-veileder-for-barne-og-ungdomsspsykiatri/Del-1/kapittel-1-diagnostikk-ibarne-og-ungdomspsykiatri/

(19) Attention deficit hyperactivity disorder: diagnosis and management, NICE guidelines [CG72]: National Institute for Health and Care Excellence; September 2008. [updated February 2015]. Available from: http://www.nice.org.uk/guidance/cg72.

Anastopoulos AD, Shelton TL. Assessing attention-deficit/hyperactivity disorder. 31 May 2001. Topics in Social Psychiatry. New York: Kluwer Academic/Plenum Publishers. P.44.

Brown TE. ADHD Comorbidities: Handbook for ADHD Complications in Children and Adults, 2009. Washington, DC: American Psychiatric Publishing. p. 87.

Hill JC, Schoener EP. Age-dependent decline of attention deficit hyperactivity disorder. Am J Psychiatry. 1996 Sep;153(9):1143-6.

Mannuzza S, Klein RG, Bessler A, Malloy P, LaPadula M. Adult outcome of hyperactive boys. Educational achievement, occupational rank and psychiatric status. Arch Gen Psychiatry1993; 50:565-76

Sonuga-Barke EJ, Daley D, Thompson M. Does maternal ADHD reduce the effectiveness of parent training for preschool children's ADHD? J Am Acad Child Adolesc Psychiatry2002; 41:696-702.

Storebø OJ, Krogh HB, Ramstad E, Moreira-Maia CR, Holmskov M, Skoog M, Nilausen TD, Magnusson FL, Zwi M, Gillies D, Rosendal S, Groth C, Rasmussen KB, Gauci D, Kirubakaran R, Forsbøl B, Simonsen E, Gluud C. Methylphenidate for attentiondeficit/hyperactivity disorder in children and adolescents: Cochrane systematic review with meta-analyses and trial sequential analyses of randomised clinical trials. BMJ. 2015 Nov 25;351:h5203.

Van Lieshout M, Luman M, Twisk JW, van Ewijk H, Groenman AP, Thissen AJ, Faraone SV, Heslenfeld DJ, Hartman CA, Hoekstra PJ, Franke B, Buitelaar JK, Rommelse NN, Oosterlaan J. A 6-year follow-up of a large European cohort of children with attention-deficit/hyperactivity disorder-combined subtype: outcomes in late 
adolescence and young adulthood. Eur Child Adolesc Psychiatry. 2016 Sep;25(9):100717.

The MTA Cooperative Group. A 14-month randomized clinical trial of treatment strategies for attention-deficit/hyperactivity disorder. Multimodal Treatment Study of Children with ADHD. The MTA Cooperative Group. Arch Gen Psychiatry. 1999 Dec;56(12):1073-86.

Hinshaw SP, Arnold LE; For the MTA Cooperative Group. ADHD, Multimodal Treatment, and Longitudinal Outcome: Evidence, Paradox, and Challenge. Wiley Interdiscip Rev Cogn Sci. 2015 Jan;6(1):39-52.

$$
\text { Arnold LE, Hodgkins P, Caci H, Kahle J, Young S. Effect of treatment }
$$
modality on long-term outcomes in attention-deficit/hyperactivity disorder: a systematic review. PLoS One. 2015 Feb 25;10(2): e0116407.

Biederman J, Newcom J, Sprich S. Comorbidity of attention deficit hyperactivity disorder with conduct, depressive, anxiety and other disorders. Am J Psychiatry1991; 148:564-77.

Freeman RD, Fast DK, Burd L, Kerbeshian J, Robertson MM, Sandor P. An international perspective on Tourette syndrome: selected findings from 3,500 individuals in 22 countries. Dev Med Child Neurol2000; 42:436-47.

Gillberg C, Gillberg IC, Rasmussen P, Kadesjö B, Söderström H, Råstam M, Johnson M, Rothenberger A, Niklasson L. Co-existing disorders in ADHD -- implications for diagnosis and intervention. Eur Child Adolesc Psychiatry2004;13 (Suppl 1): I80-92. Susan Dickerson Mayes, Susan L. Calhoun, Susan E. Lane, (2002). Learning Disabilities in Children with ADHD and Other Clinical Disorders. The ADHD Report: Vol. 10, No. 6, p. 5-8. Brook DW, Brook JS, Zhang C, Koppel J. Association between attentiondeficit/hyperactivity disorder in adolescence and substance use disorders in adulthood. Arch Pediatr Adolesc Med. 2010;164(10):930-934 
Biederman J, Wilens T, Mick E, Spencer T, Faraone SV. Pharmacotherapy of attention-deficit/hyperactivity disorder reduces risk for substance use disorder. Pediatrics. 1999 Aug;104(2): e20.

Fredriksen M, Halmøy A, Faraone SV, Haavik J. Long-term efficacy and safety of treatment with stimulants and atomoxetine in adult ADHD: a review of controlled and naturalistic studies. Eur Neuropsychopharmacol. 2013 Jun;23(6):508-27.

Hazell P. The challenges to demonstrating long-term effects of psychostimulant treatment for attention-deficit/hyperactivity disorder. Curr Opin Psychiatry. 2011 Jul;24(4):286-90. Spencer T, Biederman J, Wilens T, Doyle R, Surman C, Prince J, Mick E, Aleardi M, Herzig K, Faraone S. A large, double-blind, randomized clinical trial of methylphenidate in the treatment of adults with attention-deficit/hyperactivity disorder. Biol Psychiatry. 2005 Mar 1;57(5):456-63. Engert V, Pruessner JC. Dopaminergic and Noradrenergic Contributions to Functionality in ADHD: The Role of Methylphenidate. Curr Neuropharmacol. 2008 Dec; 6(4): $322-328$. American Academy of Pediatrics. (2001). Clinical practice guidelines:

Treatment of the school-aged child with attention-deficit/hyperactivity disorder. J. of the Amer. Acad. of Pediatrics, 108 (4), 1033-1044.

(41) Concerta XL $18 \mathrm{mg}, 36 \mathrm{mg}$, and 54mg prolonged release tablets - Summary of Product Characteristics. Medicines.org.uk. Accessed on September 22 ${ }^{\text {nd }} 2016$. Available from: https://www.medicines.org.uk/emc/medicine/30451

(42) Ritalin SR sustained release tablets - Summary of Product Characteristics. Food and Drug Administration website. Accessed on September $22^{\text {nd }} 2016$. Available from:

http://www.accessdata.fda.gov/drugsatfda_docs/label/2007/010187s069,018029s040,0212 84s011lbl.pdf 
Heal DJ, Pierce DM. Methylphenidate and its isomers: their role in the treatment of attention-deficit hyperactivity disorder using a transdermal delivery system. CNS Drugs 20 (9): 713-38.

(44) Miller GM. The emerging role of trace amine-associated receptor 1 in the functional regulation of monoamine transporters and dopaminergic activity. J. Neurochem. 2011 Jan. 116 (2): 164-76.

Kaland ME, Klein-Schwartz W. Comparison of lisdexamfetamine and dextroamphetamine exposures reported to U.S. poison centers. Clin Toxicol (Phila). 2015 Jun;53(5):477-85.

Kratochvil CJ, Heiligenstein JH, Dittmann R, Spencer TJ, Biederman J, Wernicke J, Newcorn JH, Casat C, Milton D, Michelson D. Atomoxetine and methylphenidate treatment in children with ADHD. A prospective, randomized, openlabel trial. J. Am. Acad Child Adolesc Psychiatry 2002, 41, 776-84.

Hunt RD, Minderaa RB, Cohen DJ. Clonidine benefits children with attention deficit disorder and hyperactivity: report of a double-blind placebo-crossover therapeutic trial. J Am Acad Child Psychiatry 1985; 24:617-29. Rappley MD. Clinical practice. Attention deficit-hyperactivity disorder. N Eng J Med. 2005, 352(2):165-173 Felleskatalogen website, Psykostimulantia, midler ved ADHD. Accessed on September $10^{\text {th }}$ 2016. Available from: http://www.felleskatalogen.no/medisin/atcregister/N06B Catapresan (Clonidine) - Summary of Product Characteristics. Website of the Norwegian Medicines agency. Accessed on September $2^{\text {nd }}$ 2016. Available from: http://slv.no/_layouts/Preparatomtaler/Spc/0000-05818.pdf Risperidone - Summary of product characteristics. Website of the Norwegian Medicines agency. Accessed on September $2^{\text {nd }}$ 2016. Available from: https://www.legemiddelsok.no/_layouts/15/Preparatomtaler/Spc/04-3068.pdf 
Agency for Medicines and Medical Devices of Serbia Website. In Serbian: Agencija za lekove I medicinska sredstva, pretrazivanje humanih lekova. Accessed on September 2nd 2016. Available from: http://www.alims.gov.rs/ciril/lekovi/pretrazivanjehumanih-lekova/

Evans SW, Owens JS, Bunford N. Evidence-based psychosocial treatments for children and adolescents with attention-deficit/hyperactivity disorder. J Clin Child Adolesc Psychol. 2014;43(4):527-51.

Knouse LE, Safren SA. Current Status of Cognitive Behavioral Therapy for Adult Attention-Deficit Hyperactivity Disorder. Psychiatr Clin North Am. 2010 Sep; 33(3): 497-509. Graham J, Coghill D. Adverse effects of pharmacotherapies for attentiondeficit hyperactivity disorder: epidemiology, prevention and management. CNS Drugs. 2008;22(3):213-37. Upadhyaya HP, Rose K, Wang W, O’Rourke K, Sullivan B, Deas D, Brady KT. Attention-deficit/hyperactivity disorder, medication treatment, and substance use pattern among adolescents and young adults. J Child Adolesc Psychopharmacol. 2005 Oct;15(5):799-809. Wilens TE, Adler LA, Adams J, Sgambati S, Rotrosen J, Sawtelle R, Utzinger L, Fusillo S. Misuse and diversion of stimulants prescribed for ADHD: a systematic review of the literature. J Am Acad Child Adolesc Psychiatry. 2008 Jan;47(1):21-31. Graham J, Banaschewski T, Buitelaar J, Coghill D, Danckaerts M, Dittmann RW, Döpfner M, Hamilton R, Hollis C, Holtmann M, Hulpke-Wette M, Lecendreux M, Rosenthal E, Rothenberger A, Santosh P, Sergeant J, Simonoff E, Sonuga-Barke E, Wong IC, Zuddas A, Steinhausen HC, Taylor E. European Guidelines Group European Guidelines Group. European guidelines on managing adverse effects of medication for ADHD. Eur Child Adolesc Psychiatry. 2011 Jan; 20(1): 17-37. Jasinski DR, Faries DE, Moore RJ, Schuh LM, Allen AJ. Abuse liability assessment of atomoxetine in a drug-abusing population Drug Alcohol Depend. 2008 May 1;95(1-2):140-6. 
(60) World Health Organization (November 22, 2010). "The world health report: health systems financing: the path to universal coverage". Geneva: World Health Organization. Accessed on October $7^{\text {th }}$ 2016. Available from:

http://www.who.int/whr/2010/en/

(61) International Health Comparisons: A Compendium of published information on healthcare systems, the provision of health care and health achievement in 10 countries. Accessed on October $25^{\text {th }}$ 2016. Available from: https://www.nao.org.uk/report/international-health-comparisons-a-compendium-ofpublished-information-on-healthcare-systems-the-provision-of-health-care-and-healthachievement-in-10-countries/

(62) The Norwegian health care system and pharmaceutical system. Website of the Norwegian Medicines Agency, in Norwegian Statens Legemiddelverk. Accessed on October $25^{\text {th }}$, 2016. Available from: https://legemiddelverket.no/english/about-us/thenorwegian-health-care-system-and-pharmaceutical-system

(63) Norway's Regional Health Authorities, in Norwegian: De regionale helseforetakene. Website Government.no. Accessed on November $5^{\text {th }}$ 2016. Available from: https://www.regjeringen.no/no/tema/helse-og-omsorg/sykehus/innsikt/nokkeltallog-fakta---ny/de-regionale-helseforetakene/id528110/

(64) Serbian Constitution, in Serbian: Ustav Rebuplike Srbije, article 68. Accessed on October 25, 2016. Available from: http://www.ustavni.sud.rs/page/view/sr-LatnCS/70-100028/ustav-republike-srbije

(65) Norwegian Narcotics Regulations, in Norwegian: Forskrift om narkotika. Website Lovdata.no. Accessed on October $2^{\text {nd }} 2016$. Available from: https://lovdata.no/dokument/SF/forskrift/2013-02-14-199

(66) The Medicines Regulations in Norway, in Norwegian: Forskrift om legemidler (legemiddelforskriften). Website Lovdata.no. Accessed on October $3^{\text {rd }} 2016$. Available from: https://lovdata.no/dokument/SF/forskrift/2009-12-18-1839 
World Health Organization. Lexicon of alcohol and drug terms. Accessed on October $27^{\text {th }}, 2016$. Available from:

http://www.who.int/substance_abuse/terminology/who_lexicon/en/

Law on medicines and medical devices in Serbia, in Serbian: Zakon o

lekovima i medicinskim sredstvima. Website of the Agency for Medicines and Medical

Devices of Serbia ALIMS. Accessed on October $2^{\text {nd }}$ 2016. Available from:

http://www.alims.gov.rs/eng/regulations/law-on-medicines-and-medical-devices/

Law of psychotropic controlled substances in Serbia, in Serbian: Zakon o

psihoaktivnim kontrolisanim supstancama. Website of the Serbian Ministry of Health.

Accessed on October $2^{\text {nd }}$ 2016. Available from:

http://www.zdravlje.gov.rs/downloads/Zakoni/Zakoni/ZakonOPsihoaktivnimKontrolisani $\underline{\text { mSupstancama.pdf }}$

(70) List of psychotropic controlled substances in Serbia, in Serbian: Lista

psihoaktivnih kontrolisanih supstanci. Website of Serbian's Ministry of Health. Accessed on October $3^{\text {rd }}$, 2016. Available from:

http://www.zdravlje.gov.rs/downloads/2015/April/April2015Prilog2PKS.pdf

(71) Ordinance on the prescription and dispensing of medicines in Serbia, in

Serbian: Pravilnik o nacinu propisivanja i izdavanja lekova. Accessed on October $5^{\text {th }}$

2016. Available from:

http://www.paragraf.rs/propisi/pravilnik_o_nacinu_propisivanja_i_izdavanja_lekova.html

The Norwegian Prescription Database website, in Norwegian: Reseptregisteret. Available from: http://www.norpd.no/default.aspx

Drug Consumption in Norway, in Norwegian: Legemiddelforbruk. Available from: http://www.legemiddelforbruk.no/english/

The Norwegian Institute of Public Health, in Norwegian: Folkehelseinstituttet. Available from: http://www.fhi.no/eway/default.aspx?pid=239

Björnsdóttir I, Hansen EH, Grímsson A. Quality assessment of drug sales data: the case of antibacterials in Iceland. Pharm World Sci. 1999 Oct;21(5):221-6. 
Healthcare Law in Serbia, in Serbian: Zakon o zdravstvenoj zastiti. Website of the Serbian's Ministry of Health. Accessed on October $5^{\text {th }} 2016$. Available from: http://www.zdravlje.gov.rs/tmpmz\%2Dadmin/downloads/zakoni1/zakon_zdravstvena_zas tit.pdf Ordinance on accreditation of health facilities Serbia, in Serbian: Pravilnik o akreditaciji zdravstvenih ustanova. Accessed on October $10^{\text {th }} 2016$. Available from: http://www.bolnica.org.rs/download/kvalitet/Pravilnik\%20o\%20akreditaciji\%20zdravstve nih\%20ustanova.pdf

Setlik J, Bond GR, Ho M. Adolescent prescription ADHD medication abuse is rising along with prescriptions for these medications. Pediatrics. 2009 Sep;124(3):875-80. Sciutto MJ, Eisenberg M. Evaluating the evidence for and against the overdiagnosis of ADHD. J Atten Disord. 2007 Sep;11(2):106-13.

Annual consumption of medicines. Website of the Agency for Medicines and Medical Devices of Serbia, in Serbian Agencija za lekove i medicinska sredstva ALIMS. Accessed on June $2^{\text {nd }}$ 2016. Available at: http://www.alims.gov.rs/ciril?s=potrosnja Knellwolf AL, Deligne J, Chiarotti F, Auleley GR, Palmieri S, Boisgard CB, Panei P, Autret-Leca E. Prevalence and patterns of methylphenidate use in French children and adolescents. Eur J Clin Pharmacol. 2008 Mar;64(3):311-7.

Attention-Deficit / Hyperactivity Disorder (ADHD): Data and Statistics. Website Centers for Disease Control and Prevention. Accessed on October $20^{\text {th }} 2016$. Available from: http://www.cdc.gov/ncbddd/adhd/data.html Attention deficit / hyperactivity disorder Robert Koch Institute, in German: Erkennen - Bewerten - Handeln: Zur Gesundheit von Kindern und Jugendlichen in Deutschland. - Kapitel 2.8 Aufmerksamkeitsdefizit-/Hyperaktivitätsstörung Robert Koch Institute. 27 November 2008. Accessed on October $26^{\text {th }}$ 2016. Available from: http://www.rki.de/DE/Content/Gesundheitsmonitoring/Studien/Kiggs/Basiserhebung/KiG GS_GPA.pdf? blob=publicationFile 
Attention deficit hyperactivity disorder: diagnosis and management. Clinical guideline [CG72]. Website NICE guidance. Published date: September 2008. Accessed on October $25^{\text {th }}$ 2016. Available from: https://www.nice.org.uk/guidance/CG72

Rucklidge JJ. Gender differences in attention-deficit/hyperactivity disorder. Psychiatr Clin North Am. 2010 Jun;33(2):357-73.

Biederman J, Mick E, Faraone SV, Braaten E, Doyle A, Spencer T, Wilens TE, Frazier E, Johnson MA. Influence of gender on attention deficit hyperactivity disorder in children referred to a psychiatric clinic. Am J Psychiatry. 2002 Jan;159(1):36-42.

Hanne Maria Holm. Bruk av ADHD medisin i de nordiske landene. Master thesis, 2016. Retrieved from DUO vitenarkiv-Universitetsbiblioteket, available at: http://urn.nb.no/URN:NBN:no-54052

Schirm E, Tobi H, Zito JM, de Jong-van den Berg LT. Psychotropic medication in children: a study from the Netherlands. Pediatrics. 2001 Aug;108(2): E25.

$$
\text { Kessler RC, Adler L, Barkley R, Biederman J, Conners CK, Demler O, }
$$
Faraone SV, Greenhill LL, Howes MJ, Secnik K, Spencer T, Ustun TB, Walters EE, Zaslavsky AM. The prevalence and correlates of adult ADHD in the United States: Results from the national comorbidity survey replication. Am J Psychiatry. 2006, 163(4): 716-723.

(90) Polanczyk G, de Lima MS, Horta BL, Biederman J, Rohde LA. The worldwide prevalence of ADHD: a systematic review and metaregression analysis. Am J Psychiatry. 2007 Jun; 164(6):942-8.

(91) Dalsgaard S. Attention-deficit/hyperactivity disorder (ADHD). Eur Child Adolesc Psychiatry. 2013 Feb; 22 Suppl 1: S43-8.

(92) Monteith S, Glenn T, Bauer R, Conell J, Bauer M. Availability of prescription drugs for bipolar disorder at online pharmacies. J Affect Disord. 2016 Mar 15; 193:59-65.

(93) Sayal K, Goodman R, Ford T. Barriers to the identification of children with attention deficit/hyperactivity disorder. J Child Psychol Psychiatry. 2006 Jul; 47(7):74450. 
(94) Markovic J, Rescorla L, Okanovic P, Maras JS, Bukurov KG, Sekulic S.

Assessment of preschool psychopathology in Serbia. Res Dev Disabil. 2016 Feb-Mar; 4950:216-25. 


\section{Appendix}

\section{Appendix 1}

The table shows the number of users per 1000 inhabitants for all ADHD medicines, just for methylphenidate, just for atomoxetine and just for dexamphetamine in Norway for the period of 2004 to 2014. It also shows the turnover by DDD (defined daily doses) per 1000 inhabitants per day of all ADHD medications in Norway for the period of 2004 to 2014. All data is acquired from open data in the Norwegian prescription register available online (72).

\begin{tabular}{|c|l|l|l|l|l|}
\hline Year & $\begin{array}{l}\text { Users per 1000 } \\
\text { inhabitants } \\
\text { per year all } \\
\text { ADHD } \\
\text { medicines } \\
\text { Norway }\end{array}$ & $\begin{array}{l}\text { Users per 1000 } \\
\text { inhabitants } \\
\text { per year } \\
\text { methylphenida } \\
\text { te Norway }\end{array}$ & $\begin{array}{l}\text { Users per } \\
\text { 1000 } \\
\text { inhabitants } \\
\text { per year } \\
\text { atomoxetine } \\
\text { Norway }\end{array}$ & $\begin{array}{l}\text { Users per } \\
\mathbf{1 0 0 0} \\
\text { inhabitants } \\
\text { per year } \\
\text { dexampheta } \\
\text { mine Norway }\end{array}$ & $\begin{array}{l}\text { Turnover in } \\
\text { DDD/1000/day } \\
\text { of ADHD } \\
\text { medications in } \\
\text { Norway }\end{array}$ \\
\hline 2004 & 2.59 & 2.37 & 0.18 & 0.12 & 2.63 \\
\hline 2005 & 3.59 & 3.14 & 0.69 & 0.13 & 3.68 \\
\hline 2006 & 4.06 & 3.49 & 0.69 & 0.14 & 4.35 \\
\hline 2007 & 4.65 & 4.08 & 0.68 & 0.15 & 5.26 \\
\hline 2008 & 5.16 & 4.57 & 0.68 & 0.18 & 6.08 \\
\hline 2009 & 5.64 & 5.02 & 0.67 & 0.21 & 6.53 \\
\hline 2010 & 6.02 & 5.41 & 0.62 & 0.24 & 7.08 \\
\hline 2011 & 6.16 & 5.51 & 0.63 & 0.26 & 7.41 \\
\hline 2012 & 6.44 & 5.78 & 0.60 & 0.29 & 7.52 \\
\hline 2013 & 6.70 & 5.98 & 0.65 & 0.33 & 7.73 \\
\hline 2014 & 7.08 & 6.30 & 0.71 & 0.37 & 8.21 \\
\hline
\end{tabular}




\section{Appendix 2}

Tables show the number of ADHD cases, the total number of all psychiatric cases per year and the number of newly diagnosed ADHD cases at the CNPCY in Belgrade, Serbia from 2010 - 2015. It is afterwards divided by gender. This data is not open data, and it was acquired via correspondence with the psychiatrists who work at the clinic. The data was gathered from the patients' medical records. The ratio of ADHD patients out of all patients is calculated based on the total number of ADHD case per year and the total number of all psychiatric cases for that year. The number of new ADHD cases expressed as the ratio of total number of patients based on the number of newly diagnosed ADHD cases and the total number of all psychiatric cases for that year.

\begin{tabular}{|c|c|c|c|c|c|c|}
\hline & $\begin{array}{l}\text { Number } \\
\text { of ADHD } \\
\text { cases at } \\
\text { CNPCY } \\
\text { per year }\end{array}$ & $\begin{array}{l}\text { The ratio of } \\
\text { ADHD } \\
\text { patients out } \\
\text { of all } \\
\text { patients at } \\
\text { the CNPCY, } \\
\text { Belgrade, } \\
\text { Serbia }\end{array}$ & $\begin{array}{l}\text { Number of } \\
\text { new ADHD } \\
\text { cases } \\
\text { expressed as } \\
\text { the ratio of } \\
\text { total number } \\
\text { of patients at } \\
\text { CNPCY, } \\
\text { Belgrade, } \\
\text { Serbia }\end{array}$ & $\begin{array}{c}\text { Total } \\
\text { number of } \\
\text { psychiatric } \\
\text { diagnosis } \\
\text { per year }\end{array}$ & $\begin{array}{c}\text { Total } \\
\text { number of } \\
\text { psychiatric } \\
\text { diagnosis } \\
\text { per year } \\
\text { Boys }\end{array}$ & $\begin{array}{c}\text { Total } \\
\text { number of } \\
\text { psychiatric } \\
\text { diagnosis } \\
\text { per year } \\
\text { Girls }\end{array}$ \\
\hline 2010 & 74 & $4 \%$ & N/A & 1817 & 981 & 836 \\
\hline 2011 & 123 & $7 \%$ & $5 \%$ & 1861 & 1036 & 825 \\
\hline 2012 & 118 & $7 \%$ & $4 \%$ & 1745 & 1000 & 745 \\
\hline 2013 & 110 & $6 \%$ & $3 \%$ & 1741 & 979 & 762 \\
\hline 2014 & 153 & $8 \%$ & $4 \%$ & 1897 & 1098 & 799 \\
\hline 2015 & 161 & $8 \%$ & $4 \%$ & 1997 & 1144 & 853 \\
\hline
\end{tabular}

Total number of F90 diagnosis per year

\begin{tabular}{|l|r|r|r|r|r|r|}
\hline & \multicolumn{1}{|c|}{ Total } & \multicolumn{1}{|c|}{ Boys } & \multicolumn{1}{c|}{ Girls } & \multicolumn{2}{|c|}{$\begin{array}{c}\text { New cases } \\
\text { Total }\end{array}$} & \multicolumn{2}{|c|}{$\begin{array}{c}\text { New cases } \\
\text { Boys }\end{array}$} & New cases Girls \\
\hline Year 2010 & 74 & 67 & 7 & N/A & N/A & N/A \\
\hline Year 2011 & 123 & 103 & 20 & 87 & 72 & 15 \\
\hline Year 2012 & 118 & 106 & 12 & 64 & 57 & 7 \\
\hline Year 2013 & 110 & 95 & 15 & 50 & 39 & 11 \\
\hline Year 2014 & 153 & 136 & 17 & 85 & 75 & 26 \\
\hline Year 2015 & 161 & 126 & 35 & 81 & 55 & 10 \\
\hline
\end{tabular}




\section{Appendix 3}

The table shows a number of users of ADHD medicines in Norway, expressed as a total number of methylphenidate users per year, expressed as a total number of dexamphetamine users per year, and expressed as total number of atomoxetine users per year during the period of 2004 to 2014. All data is acquired from open data in the Norwegian prescription register available online (72).

\begin{tabular}{|r|r|r|r|}
\hline & $\begin{array}{c}\text { Number of } \\
\text { methylphenidate } \\
\text { users in Norway }\end{array}$ & $\begin{array}{c}\text { Number of } \\
\text { dexamphetamine } \\
\text { users in Norway }\end{array}$ & $\begin{array}{c}\text { Number of } \\
\text { atomoxetine } \\
\text { users in Norway }\end{array}$ \\
\hline 2004 & 10866 & 545 & 838 \\
\hline 2005 & 14528 & 595 & 3203 \\
\hline 2006 & 16273 & 633 & 3207 \\
\hline 2007 & 19199 & 722 & 3184 \\
\hline 2008 & 21769 & 857 & 3246 \\
\hline 2009 & 24240 & 1024 & 3213 \\
\hline 2010 & 26471 & 1167 & 3055 \\
\hline 2011 & 27302 & 1285 & 3108 \\
\hline 2012 & 28985 & 1473 & 3035 \\
\hline 2013 & 30396 & 1691 & 3281 \\
\hline 2014 & 32344 & 1885 & 3635 \\
\hline
\end{tabular}




\section{Appendix 4}

The table shows the use of the three main substances used in ADHD treatment:

methylphenidate, dexamphetamine, atomoxetine. It is expressed as the number of defined daily doses per 1000 inhabitants per day. All data is acquired from open data in the Norwegian prescription register and from the Norwegian Drug Consumption website. All data is available online and is available in hardcopy (72).

\begin{tabular}{|r|r|r|r|}
\hline & $\begin{array}{c}\text { DDD/1000/day } \\
\text { methylphenidate in } \\
\text { Norway }\end{array}$ & $\begin{array}{c}\text { DDD/1000/day } \\
\text { dexamphetamine in } \\
\text { Norway }\end{array}$ & $\begin{array}{c}\text { DDD/1000/day } \\
\text { atomoxetine in } \\
\text { Norway }\end{array}$ \\
\hline 2004 & 2.43 & 0.14 & 0.01 \\
\hline 2005 & 3.22 & 0.16 & 0.21 \\
\hline 2006 & 3.87 & 0.20 & 0.28 \\
\hline 2007 & 4.59 & 0.23 & 0.28 \\
\hline 2008 & 5.26 & 0.30 & 0.28 \\
\hline 2009 & 5.74 & 0.35 & 0.27 \\
\hline 2010 & 6.21 & 0.38 & 0.25 \\
\hline 2011 & 6.28 & 0.43 & 0.25 \\
\hline 2012 & 6.72 & 0.50 & 0.23 \\
\hline 2013 & 6.93 & 0.58 & 0.24 \\
\hline 2014 & 7.36 & 0.65 & 0.26 \\
\hline
\end{tabular}

\begin{tabular}{|r|l|r|}
\hline & $\begin{array}{l}\text { Consumption in } \\
\text { DDD/1000/day of ADHD } \\
\text { medications in Norway }\end{array}$ & $\begin{array}{l}\text { Consumption in } \\
\text { DDD/1000/day of } \\
\text { methylphenidate in } \\
\text { Norway }\end{array}$ \\
\hline 2004 & 2.63 & 2.43 \\
\hline 2005 & 3.68 & 3.22 \\
\hline 2006 & 4.35 & 3.87 \\
\hline 2007 & 5.26 & 4.59 \\
\hline 2008 & 6.08 & 5.26 \\
\hline 2009 & 6.53 & 5.74 \\
\hline 2010 & 7.08 & 6.21 \\
\hline 2011 & 7.41 & 6.28 \\
\hline 2012 & 7.52 & 6.72 \\
\hline 2013 & 7.73 & 6.93 \\
\hline 2014 & 8.21 & 7.36 \\
\hline & &
\end{tabular}




\section{Appendix 5}

The tables show the ADHD medication users in Norway divided by age in groups 4 years or younger, 5-9 years, 10-14 years, 15-19 years and 20 years and older and divided by both age and gender afterwards. All data is open data and it's available on the website of the Norwegian Prescription Register (72).

\begin{tabular}{|r|r|r|r|r|r|}
\hline Norway & \multicolumn{1}{|c|}{$<$ years } & \multicolumn{1}{c|}{5 -9 years } & $10-14$ years & \multicolumn{1}{c|}{ 15-19 years } & \multicolumn{1}{c|}{ 20+ years } \\
\hline 2004 & 29 & 1777 & 4555 & 2902 & 2614 \\
\hline 2005 & 27 & 2165 & 5811 & 4120 & 4455 \\
\hline 2006 & 24 & 2041 & 6225 & 4915 & 5706 \\
\hline 2007 & 22 & 2157 & 6814 & 5638 & 7280 \\
\hline 2008 & 14 & 2215 & 7294 & 6321 & 8781 \\
\hline 2009 & 13 & 2268 & 7826 & 6712 & 10424 \\
\hline 2010 & 5 & 2333 & 8140 & 7043 & 11916 \\
\hline 2011 & 8 & 2220 & 8187 & 7183 & 12926 \\
\hline 2012 & 8 & 2300 & 8219 & 7253 & 14520 \\
\hline 2013 & 8 & 2290 & 8306 & 7221 & 16194 \\
\hline 2014 & 5 & 2439 & 8392 & 7390 & 18124 \\
\hline
\end{tabular}

\begin{tabular}{|l|r|r|r|r|r|}
\hline \multicolumn{1}{|c|}{ Norway } & \multicolumn{1}{|c|}{2010} & \multicolumn{1}{c|}{2011} & \multicolumn{1}{c|}{2012} & \multicolumn{1}{c|}{2013} & \multicolumn{1}{c|}{2014} \\
\hline$<4$ Boys & 5 & 8 & 7 & 6 & 4 \\
\hline$<4$ Girls & 0 & 0 & 4 & 4 & 0 \\
\hline 5-9 Boys & 1774 & 1702 & 1774 & 1745 & 1875 \\
\hline 5-9 Girls & 559 & 518 & 526 & 545 & 564 \\
\hline 10-14 Boys & 6116 & 6132 & 6084 & 6142 & 6168 \\
\hline 10-14 Girls & 2024 & 2055 & 2135 & 2164 & 2224 \\
\hline 15-19 Boys & 4743 & 4851 & 4865 & 4834 & 4861 \\
\hline 15-19 Girls & 2300 & 2332 & 2388 & 2387 & 2529 \\
\hline
\end{tabular}




\section{Appendix 6}

The tables show the distribution by age of ADHD cases at the Clinic for Neurology and Psychiatry for Children and Youth in the capital Belgrade, Serbia from 2010-2014. Data is divided by age in groups 4 years or younger, 5-9 years, 10-14 years and 15-19 years of age, and divided by both age and gender afterwards. The data is not open data and it is collected from patients' medical records.

\begin{tabular}{|l|r|r|r|r|r|}
\hline Serbia & $\mathbf{2 0 1 0}$ & $\mathbf{2 0 1 1}$ & $\mathbf{2 0 1 2}$ & $\mathbf{2 0 1 3}$ & $\mathbf{2 0 1 4}$ \\
\hline$<4$ years & 1 & 11 & $\mathbf{7}$ & 0 & 2 \\
\hline 5-9 years & 32 & 43 & 43 & 42 & 51 \\
\hline $\mathbf{1 0 - 1 4}$ years & 37 & 59 & 64 & 55 & 77 \\
\hline $\mathbf{1 5 - 1 9}$ years & 4 & 10 & 4 & 13 & 23 \\
\hline
\end{tabular}

\begin{tabular}{|l|r|r|r|r|r|}
\hline Serbia & $\mathbf{2 0 1 0}$ & $\mathbf{2 0 1 1}$ & $\mathbf{2 0 1 2}$ & $\mathbf{2 0 1 3}$ & $\mathbf{2 0 1 4}$ \\
\hline <4 years boys & 1 & $\mathbf{8}$ & 7 & 0 & 1 \\
\hline $\mathbf{5 - 9}$ years boys & 29 & 39 & 40 & 35 & 45 \\
\hline $\mathbf{1 0 - 1 4}$ years boys & 33 & 46 & 55 & 49 & 69 \\
\hline $\mathbf{1 5 - 1 9}$ years boys & 4 & 10 & 4 & 11 & 21 \\
\hline
\end{tabular}

\begin{tabular}{|l|r|r|r|r|r|}
\hline Serbia & $\mathbf{2 0 1 0}$ & $\mathbf{2 0 1 1}$ & $\mathbf{2 0 1 2}$ & $\mathbf{2 0 1 3}$ & $\mathbf{2 0 1 4}$ \\
\hline <4 years girls & 0 & 3 & 0 & 0 & 1 \\
\hline 5-9 years girls & 3 & 4 & 3 & 7 & 6 \\
\hline $10-14$ years girls & 4 & 13 & 9 & 6 & 8 \\
\hline $15-19$ years girls & 0 & 0 & 0 & 2 & 2 \\
\hline
\end{tabular}




\section{Appendix 7}

Table shows number of ADHD medication users divided by gender during the period of 2004-2014. The data is open data and it is available on the website of the Norwegian Prescription database (72).

\begin{tabular}{|c|c|c|}
\hline & $\begin{array}{l}\text { Number of male users of } \\
\text { ADHD medications per year } \\
\text { in Norway }\end{array}$ & $\begin{array}{l}\text { Number of female users of } \\
\text { ADHD medications per year in } \\
\text { Norway }\end{array}$ \\
\hline 2004 & 9157 & 2722 \\
\hline 2005 & 12261 & 4319 \\
\hline 2006 & 13503 & 5408 \\
\hline 2007 & 15124 & 6787 \\
\hline 2008 & 16502 & 8122 \\
\hline 2009 & 17841 & 9402 \\
\hline 2010 & 18971 & 10467 \\
\hline 2011 & 19515 & 11010 \\
\hline 2012 & 20302 & 11999 \\
\hline 2013 & 21130 & 12891 \\
\hline 2014 & 22241 & 14108 \\
\hline
\end{tabular}

\begin{tabular}{|c|c|c|c|c|}
\hline & $\begin{array}{c}\text { Male } \\
\text { population } \\
\text { Norway }\end{array}$ & $\begin{array}{c}\text { Female } \\
\text { population } \\
\text { Norway }\end{array}$ & $\begin{array}{l}\text { Male } \\
\text { population } \\
\text { Serbia* }\end{array}$ & $\begin{array}{l}\text { Female } \\
\text { population } \\
\text { Serbia* }\end{array}$ \\
\hline 2010 & $64.40 \%$ & $35.60 \%$ & $90.50 \%$ & $9.50 \%$ \\
\hline 2011 & $64.00 \%$ & $36.00 \%$ & $83.70 \%$ & $16.30 \%$ \\
\hline 2012 & $62.80 \%$ & $37.20 \%$ & $89.80 \%$ & $10.20 \%$ \\
\hline 2013 & $62.10 \%$ & $37.90 \%$ & $86.40 \%$ & $13.60 \%$ \\
\hline 2014 & $61.20 \%$ & $38.80 \%$ & $88.90 \%$ & $11.10 \%$ \\
\hline
\end{tabular}




\section{Appendix 8}

Table shows the distribution by gender of ADHD cases in the Clinic for Neurology and Psychiatry for Children and Youth, Belgrade, Serbia from 2010-2015. The data is not open data, and it was acquired via correspondence with the psychiatrists who work at the clinic. The data was gathered from the patients' medical records.

\begin{tabular}{|r|r|r|}
\hline \multicolumn{3}{|c|}{ Number of ADHD cases in Serbia 2010- } \\
\hline & \multicolumn{1}{|c|}{ Boys } & \multicolumn{1}{c|}{ Girls } \\
\hline $\mathbf{2 0 1 0}$ & 67 & 7 \\
\hline $\mathbf{2 0 1 1}$ & 103 & 20 \\
\hline $\mathbf{2 0 1 2}$ & 106 & 12 \\
\hline $\mathbf{2 0 1 3}$ & 95 & 15 \\
\hline $\mathbf{2 0 1 4}$ & 136 & 17 \\
\hline $\mathbf{2 0 1 5}$ & 126 & 35 \\
\hline
\end{tabular}

\section{Appendix 9}

The table the assigned treatment of newly diagnosed patients in the biggest diagnostics center in the Serbia's capital Belgrade, from the Clinic for Neurology and Psychiatry for Children and Youth in 2015. The data is not open data, and it was acquired via correspondence with the psychiatrists who work at the clinic. The data was gathered from the patients' medical records.

\begin{tabular}{|c|l|l|l|l|}
\hline Year 2015 & $\begin{array}{l}\text { Patients } \\
\text { who } \\
\text { received } \\
\text { Concerta }\end{array}$ & $\begin{array}{l}\text { Patients who } \\
\text { received } \\
\text { Risperidone }\end{array}$ & $\begin{array}{l}\text { Patients who } \\
\text { received other } \\
\text { treatment: CBT, } \\
\text { parent counseling }\end{array}$ & $\begin{array}{c}\text { Total } \\
\text { number of } \\
\text { patients }\end{array}$ \\
\hline $\begin{array}{c}\text { Therapy } \\
\text { Serbia }\end{array}$ & & 15 & & 97 \\
\hline \\
& 45 & $9.60 \%$ & & \\
\hline
\end{tabular}




\section{Appendix 10}

The tables show the distribution of different methylphenidate preparations within the ATC

N06BA04: Ritalin, Concerta, Equasym and Medikinet during the period 2010-2014 This is not open data and it was obtained from the Norwegian Institute of Public Health via correspondence.

\begin{tabular}{|c|c|c|c|}
\hline Medication & Year & Number of users & DDD \\
\hline \multirow[t]{5}{*}{ Concerta } & 2010 & 11794 & 5153500 \\
\hline & 2011 & 12526 & 5369017 \\
\hline & 2012 & 13265 & 5409557 \\
\hline & 2013 & 13667 & 5477542 \\
\hline & 2014 & 13867 & 5645347 \\
\hline \multirow[t]{5}{*}{ Equasym } & 2010 & 1702 & 375162 \\
\hline & 2011 & 1738 & 398975 \\
\hline & 2012 & 1872 & 426013 \\
\hline & 2013 & 1863 & 438615 \\
\hline & 2014 & 1852 & 446970 \\
\hline \multirow[t]{5}{*}{ Ritalin } & 2010 & 17200 & 5845486 \\
\hline & 2011 & 17092 & 6139327 \\
\hline & 2012 & 17885 & 6252852 \\
\hline & 2013 & 18563 & 6444233 \\
\hline & 2014 & 19964 & 6946514 \\
\hline \multirow[t]{5}{*}{ Medikinet } & 2010 & 368 & 33658 \\
\hline & 2011 & 706 & 99454 \\
\hline & 2012 & 1286 & 172618 \\
\hline & 2013 & 1918 & 262937 \\
\hline & 2014 & 2562 & 374732 \\
\hline
\end{tabular}




\section{Appendix 11}

The table shows the use of methylphenidate in Norway and Serbia expressed in defined daily dose per 1000 inhabitants per day during the period of 2007-2013. This is open data and it is available on websites of Norwegian Prescription register (72) and the Agency for Medicines and Medical Devices of Serbia (80).

\begin{tabular}{|r|r|r|}
\hline & $\begin{array}{c}\text { DDD/1000/day } \\
\text { methylphenidate } \\
\text { in Serbia }\end{array}$ & $\begin{array}{c}\text { DDD/1000/day } \\
\text { methylphenidate } \\
\text { in Norway }\end{array}$ \\
\hline 2007 & 0.005000 & 4.59 \\
\hline 2008 & 0.023000 & 5.26 \\
\hline 2009 & 0.027980 & 5.74 \\
\hline 2010 & 0.031540 & 6.21 \\
\hline 2011 & 0.033760 & 6.28 \\
\hline 2012 & 0.033861 & 6.72 \\
\hline 2013 & 0.035000 & 6.93 \\
\hline
\end{tabular}

